\title{
Estructura de la comunidad de céspedes algales en interacciones con corales masivos en arrecifes del Parque Nacional Natural Tayrona, Caribe colombiano \\ Community structure of turf algae in interactions with massive corals in Tayrona National Natural Park, Colombian Caribbean
}

\author{
Catalina Gómez-Cubillos ${ }^{{ }^{*}}$, Brigitte Gavio ${ }^{2}$ y Sven Zea ${ }^{l}$ \\ (iD $0000-0003-3384-5969$ \\ (iD) $0000-0001-5364-3374 \quad$ (D) $0000-0002-5657-4877$
}

1. Grupo de investigación Fauna Marina Colombiana: Biodiversidad y Usos, Universidad Nacional de Colombia, sede Caribe, Instituto de Estudios en Ciencias del Mar (Cecimar).Atte.Invemar,Playa Salguero,Rodadero,Santa Marta,Colombia.macgomezcu@unal.edu.co*, szeas@unal.edu.co

2. Grupo de investigación Sistemática Molecular y Biogeografia de Algas Marinas, Universidad Nacional de Colombia, sede Bogotá, Colombia.bgavio@unal.edu.co

* Autora de correspondencia.

\section{RESUMEN}

os céspedes algales son actualmente el componente bentónico más abundante en la mayoría de arrecifes coralinos. Su amplia distribución, papel funcional y respuesta positiva a factores que estresan a los corales confirma su importancia en el funcionamiento del ecosistema arrecifal. Se ha demostrado que la composición de especies, el desarrollo estructural y la retención de sedimentos influyen en su capacidad de matar y desplazar tejido coralino vivo adyacente. En este estudio en dos arrecifes del Parque Nacional Natural Tayrona (Caribe colombiano), se determinó la variación en la estructura de los céspedes establecidos y en interacción directa con corales masivos, y se relacionó su complejidad estructural con la capacidad de retención de sedimentos. Para ello, se determinó la composición taxonómica y se cuantificaron la altura del dosel, la cobertura y densidad de filamentos y la biomasa algal de los céspedes que crecían sobre colonias vivas de cuatro especies de corales. Los resultados mostraron que existen diferencias estructurales importantes entre arrecifes y tipo de sustrato. En el arrecife de Granate (10-16 m), los céspedes forman tapetes discontinuos entre algas costrosas, y están constituidos por algas calcáreas articuladas, pequeñas corticadas y juveniles de algas frondosas, principalmente del género Dictyota. Durante el afloramiento costero este género crece profusamente formando transitoriamente tapetes densos que luego se desprenden. Por el contrario, en el arrecife de Nenguange (4-6 m), los céspedes son perennes, forman tapetes muy bajos, tupidos y densos con escasas algas costrosas, y están dominados por algas filamentosas y pequeñas corticadas. Se sugiere que la presencia de territorios de damiselas del género Stegastes ayuda a controlar la complejidad estructural de los céspedes, y que la propagación vegetativa es el mecanismo de crecimiento más frecuente. Además, se encontró que los céspedes morfológicamente más complejos retienen mayor cantidad de sedimentos (limos-arcillas). Este material particulado les sirve de soporte; pueden avanzar lateralmente y ahogar el tejido coralino adyacente. Esta investigación provee los primeros datos cuantitativos de la estructura y cantidad de sedimentos retenidos por céspedes algales que crecen sobre corales arrecifales de Colombia.

PALABRAS CLAVE: arrecifes de coral, interacciones coral-césped, estructura de ensamblajes algales, retención de sedimentos, Caribe colombiano

\section{ABSTRACT}

$\mathrm{A}$ lgal turfs are currently the most abundant benthic component on most coral reefs. Their wide distribution, functional role and positive response to factors that stress corals confirm their importance in the functioning of reef ecosystem. It has been shown that species composition, structural development and sediment retention influence their capacity to kill and displace adjacent live coral tissue. In this study in two reefs of the Tayrona National Natural Park (Colombian Caribbean), the variation in structure of turfs growing on and in direct interaction with massive live corals was determined, and its structural complexity was related with its sediment retention capacity. For that, the taxonomical composition was determined, and canopy height, cover and density of filaments and algal biomass were quantified for turfs growing on live colonies of four species of corals. The results showed that there are important structural differences between reefs and substratum type. In Granate reef (10-16 m), turfs form discontinuous carpets over crustose algae, and are constituted by articulated calcareous and little corticated algae, and juveniles of frondose algae, mostly of the genus Dictyota. During coastal upwelling, this genus grows profusely forming transient dense algal beds that later detach. In contrast, in Nenguange reef (4-6 m), turfs are perennial, form low, thick and dense carpets, with few crustose algae, and are dominated by filamentous and small corticated algae. It's suggested that the presence of territories of damselfishes (Stegastes spp.) aid controlling the structural complexity of the turfs, and that vegetative propagation is the most frequent growth mechanism. In addition, it was found that the most morphologically complex turfs can retain greater amounts of sediments (silt-clay). This particulate material supports them; they can advance laterally and smother adjacent live coral tissue. This investigation provides the first quantitative data on the structure and amount of retained sediments by algal turfs growing on Colombian reef corals.

KEY WORDS: coral reefs, algal turfs, interactions, structure of algal assemblages, sediment retention, colombian Caribbean

DOI: https://doi.org/10.25268/bimc.invemar.2020.49.SuplEsp.1053

Publicado por INVEMAR

Published by INVEMAR

Este es un manuscrito de acceso abierto bajo la licencia CC

Reconocimiento-No Comercial-Compartir Igual 


\section{INTRODUCCIÓN}

Actualmente los céspedes algales son el componente bentónico más abundante en la mayoría de arrecifes de coral (Gorgula y Connell, 2004; Fricke et al., 2011; Harris, 2015), fenómeno confirmado para algunos arrecifes continentales e insulares del Caribe colombiano (Gómez-Cubillos et al., 2019, en prensa).

Esta tendencia global, al parecer, es en respuesta a varias perturbaciones de origen antropogénico (Jackson et al., 2014), que en suma han reducido la capacidad de recuperación de los corales, pero que han favorecido la proliferación de los céspedes algales a expensas de los constructores de arrecife (Roy, 2004; Barott et al., 2012; Bender-Champ et al., 2014). Este fenómeno se ha considerado un "cambio de fase", donde los arrecifes coralinos ahora son dominados por comunidades algales (Jompa y McCook, 2003a; McManus y Polsenberg, 2004), particularmente por céspedes, ensamblajes ubicuos que pueden actuar como facilitadores de este cambio (Barott et al., 2012), ya que una vez establecidos los céspedes luego de la mortalidad coralina, limitan la regeneración natural del tejido coralino y el reclutamiento larval (Hughes, 1966).

Los céspedes son ensamblajes mixtos de algas, densamente agregados, con altura de dosel no mayor a $2 \mathrm{~cm}$ y compuestos por una gran variedad de grupos que incluyen cianobacterias y algas rojas, verdes y pardas (BenderChamp et al., 2014; Connell et al., 2014; Harris, 2015). Dependiendo del hábitat donde se desarrollan, exhiben gran variedad de morfologías, siendo las formas filamentosas (corticadas y no corticadas), las pequeñas foliáceas y las calcáreas articuladas las más frecuentes (Connell et al., 2014; Cetz-Navarro et al., 2015). En comparación con otras formas funcionales como las algas carnosas (calcáreas y no calcáreas) y algas costrosas, los céspedes poseen ventajas competitivas que les permiten colonizar el espacio disponible más rápidamente (Díaz-Pulido y McCook, 2002), al tener altas tasas de crecimiento (Littler et al., 2006), ser menos vulnerables a perturbaciones (Hay, 1981) y desarrollarse en ambientes con sobrecarga de nutrientes y alta sedimentación (Airoldi y Virgilio, 1998; Gorgula y Connell, 2004). Asimismo, estudios experimentales han demostrado que, en aguas más cálidas y ácidas, los céspedes obtienen mejores tasas fotosintéticas y mayor crecimiento; es decir, que su fisiología es influenciada positivamente por el calentamiento y la acidificación de los océanos (Kroeker et al., 2013; Ober et al., 2016; Johnson et al., 2017).

\section{INTRODUCTION}

Currently, algae turfs are the most abundant benthic component in most coral reefs (Gorgula and Connell, 2004; Fricke et al., 2011; Harris, 2015), a phenomenon confirmed for some continental and insular reefs of the Colombian Caribbean (Gómez-Cubillos et al., 2019; in press).

This global trend is in response to various disturbances of anthropogenic origin (Jackson et al., 2014), which in sum have reduced the capacity of corals to recover, but which have favored the proliferation of algae turfs at the expense of reef builders (Roy, 2004; Barott et al., 2012; Bender-Champ et al., 2014). This phenomenon has been considered a "phase change", where coral reefs are now dominated by algal communities (Jompa and McCook, 2003a; McManus and Polsenberg, 2004), particularly by turfs, ubiquitous assemblages that can act as facilitators of this change (Barott et al., 2012), since once the turfs are established after coral mortality, they limit the natural regeneration of coral tissue and larval recruitment (Hughes, 1966).

Turfs are mixed assemblages of algae, densely aggregated, with a canopy height of no more than $2 \mathrm{~cm}$ and composed of a wide variety of groups that include cyanobacteria and red, green, and brown algae (BenderChamp et al., 2014; Connell et al., 2014; Harris, 2015). Depending on the habitat where they develop, they exhibit a great variety of morphologies, being the filamentous forms (corticated and not corticated), the small foliaceous, and the articulated calcareous ones the most frequent (Connell et al., 2014; Cetz-Navarro et al., 2015). Compared with other functional forms such as fleshy algae (calcareous and non-calcareous) and crusty algae, turfs have competitive advantages that allow them to colonize the available space more quickly (Díaz-Pulido and McCook, 2002), as they have high growth rates (Littler et al., 2006), be less vulnerable to disturbances (Hay, 1981) and thrive in environments with nutrient overload and high sedimentation (Airoldi and Virgilio, 1998; Gorgula and Connell, 2004). Likewise, experimental studies have shown that, in warmer and more acidic waters, turfs obtain better photosynthetic rates and higher growth; that is, their physiology is positively influenced by the warming and acidification of the oceans (Kroeker et al., 2013; Ober et al., 2016; Johnson et al., 2017).

Turfs play important ecological roles in reefs since they are the main source of primary productivity 
Los céspedes desempeñan importantes roles ecológicos en los arrecifes, ya que son la principal fuente de productividad primaria (Bellwood et al., 2004; Carpenter y Williams, 2007), facilitan el reciclaje de nutrientes (Copertino et al., 2005; Gowan et al., 2014) y son hábitat y alimento para numerosas especies de invertebrados y peces (Harris, 2015). No obstante, también se ha demostrado que tienen un impacto negativo, ya que como sustrato poblado limitan el establecimiento exitoso de larvas de coral y otros organismos (Garzón-Ferreira et al., 2002; Airoldi, 2003; Birrell et al., 2005, 2008; Hughes et al., 2007). Además, son el principal competidor contra corales duros (Roy, 2004; Barott et al., 2012; Harris, 2015; Swierts y Vermeij, 2016), pues, al quedar expuestos los esqueletos de corales por lesiones previas, los céspedes los colonizan rápidamente, y una vez se establecen, interactúan con el tejido coralino adyacente ocasionando su muerte lenta y progresiva, mecanismo que varía según la especie de coral involucrada (Gómez-Cubillos, 2018).

Adicionalmente, Roy (2004) sugiere que en áreas con alta carga de sedimentos y resuspensión existe un problema adicional para los corales, ya que en bordes de tejido coralino vivo en interacción con céspedes, los filamentos algales ralentizan los flujos de agua, atrapando sedimentos y formando esteras de algas con sedimentos, que disuaden la acción de los herbívoros y reducen la capacidad competitiva de las diferentes formas de crecimiento de los corales para evadir y/o combatir directamente a los céspedes (Zhiheng et al., 2019), lo que a futuro genera muerte progresiva del tejido coralino adyacente. Al respecto, Nugues y Roberts (2003) encontraron que, en los arrecifes de Santa Lucia, los incrementos en la sedimentación les permiten a los céspedes recubrir con mayor rapidez a los corales, y que los sedimentos retenidos por los céspedes, sofocan y matan el tejido adyacente, principalmente durante la temporada de lluvias. Lo anterior demuestra que los céspedes con sedimentos juegan un papel clave en la mortalidad coralina y justifica la necesidad de caracterizar estructuralmente la comunidad de céspedes algales para establecer si la estructura de estos ensamblajes influye en su capacidad de retener de sedimentos.

En tal sentido, es posible sugerir que la abundancia de céspedes algales es una evidencia de las perturbaciones que afectan a los arrecifes, ya que se mantienen y proliferan en condiciones que son de estrés para los corales y otros organismos calcificadores (Díaz-Pulido y McCook, 2002; Airoldi, 2003; Barott et al., 2012; Bender-Champ et al.,
(Bellwood et al., 2004; Carpenter and Williams, 2007), they facilitate the recycling of nutrients (Copertino et al., 2005; Gowan et al., 2014) and are habitat and food for numerous species of invertebrates and fish (Harris, 2015). However, it has also been shown that they have a negative impact since as a populated substrate they limit the successful establishment of coral larvae and other organisms (Garzón-Ferreira et al., 2002; Airoldi, 2003; Birrell et al., 2005, 2008; Hughes et al., 2007). Also, they are the main competitor against hard corals (Roy, 2004; Barott et al., 2012; Harris, 2015; Swierts and Vermeij, 2016) because, when the coral skeletons are exposed due to previous injuries, the turfs quickly colonize them, and once they are established, they interact with the adjacent coral tissue causing their slow and progressive death, a mechanism that varies according to the coral species involved (Gómez-Cubillos, 2018).

Additionally, Roy (2004) suggests that in areas with high sediment load and resuspension, there is an additional problem for corals, since, at the edges of living coral tissue interacting with turfs, the algal filaments slow down water flows, trapping sediments and forming algae mats with sediments, which discourage the action of herbivores and reduce the competitive capacity of different forms of coral growth to evade and/or directly combat turfs (Zhiheng et al., 2019), which in the future it generates progressive death of the adjacent coral tissue. In this regard, Nugues and Roberts (2003) found that, in the reefs of Santa Lucia, the increases in sedimentation allow the turfs to cover the corals more quickly, and that the sediments retained by the turfs suffocate and kill the adjacent tissue, mainly during the rainy season. The foregoing shows that turfs with sediments play a key role in coral mortality, and justifies the need to structurally characterize the community of algal turfs to establish whether the structure of these assemblages influences their ability to retain sediments.

In this sense, it is possible to suggest that the abundance of algae turfs is evidence of the disturbances that affect reefs, since they are maintained and proliferate in conditions that are stressful for corals and other calcifying organisms (Díaz-Pulido and McCook, 2002; Airoldi, 2003; Barott et al., 2012; Bender-Champ et al., 2014). Also, the dynamics of coral-turf interactions represent an indicator of the resilience and future of coral communities, since not only the presence of turf affects corals, but also their species composition (Jompa and McCook, 2003b). 
2014). Además, la dinámica de interacciones coral-césped representa un indicador de la capacidad de recuperación y futuro de las comunidades coralinas, pues no solo la presencia del césped afecta a los corales, sino también su composición de especies (Jompa y McCook, 2003b).

A pesar de que en los últimos años se han incrementado el número de informes mundiales sobre la presencia de céspedes algales que se expanden a expensas de corales hermatípicos (Connell et al., 2014; Harris, 2015), estos ensamblajes han sido escasamente caracterizados debido a su alta diversidad, al tamaño reducido de las especies que los componen, su plasticidad morfológica y alternancia de ciclos de vida (Díaz-Pulido y McCook, 2002; Fricke et al., 2011). Por lo tanto, su estudio se limita a registros generalizados como un grupo funcional homogéneo, y no como una comunidad, que cumple diversas funciones ecológicas dependiendo de su composición (Harris, 2015). No obstante, Díaz-Pulido y McCook (2002) y Fricke et al. (2011) estimaron que en arrecifes de la Gran Barrera de Coral y Curazao la composición de los ensamblajes de céspedes algales pueden incluir al menos 35 taxa diferentes.

Reconociendo la importancia ecológica y los vacíos de conocimiento sobre los céspedes, en este estudio se realizó la caracterización estructural de los ensamblajes que crecen sobre partes muertas de colonias vivas de cuatro especies de corales masivos morfológicamente contrastantes, en dos arrecifes del Parque Nacional Natural Tayrona (PNN Tayrona), Caribe colombiano. Esto con el fin de relacionar la complejidad estructural de estos ensamblajes con la capacidad de retención de sedimentos, y sentar las bases para interpretar las condiciones en las cuales estos céspedes avanzan o retroceden en la frontera de interacción con el tejido vivo de los corales que han colonizado (Gómez-Cubillos, 2018).

Con esta investigación se contribuye al conocimiento sobre la diversidad de algas en el país y se presentan las primeras referencias cuantitativas sobre la estructura y cantidad de sedimentos retenidos por céspedes algales que crecen sobre esqueletos coralinos en arrecifes de Colombia.

\section{ÁREA DE ESTUDIO}

Los arrecifes coralinos que bordean el litoral rocoso del PNN Tayrona (Figura 1, $11^{\circ} 12^{\prime}-11^{\circ} 22^{\prime} \mathrm{N}$ y $73^{\circ} 57^{\prime}-$ $74^{\circ} 15^{\prime} \mathrm{W}$ ) son poco amplios, de tipo franjeante y constituidos principalmente por corales masivos hemisféricos. A pesar
Even though in recent years the number of world reports on the presence of algal turfs expanding at the expense of hermatypic corals has increased (Connell et al., 2014; Harris, 2015), these assemblages have been poorly characterized due to to their high diversity, the reduced size of the species that compose them, their morphological plasticity and alternation of life cycles (Díaz-Pulido and McCook 2002; Fricke et al., 2011). Therefore, their study is limited to generalized records as a homogeneous functional group, and not as a community, which fulfills various ecological functions depending on its composition (Harris, 2015). However, Díaz-Pulido and McCook (2002) and Fricke et al. (2011) estimated that in reefs of the Great Barrier Reef and Curaçao, the composition of algal turf assemblages may include at least 35 different taxa.

Recognizing the ecological importance and knowledge gaps about turfs, in this study the structural characterization of the assemblages that grow on dead parts of living colonies of four species of morphologically contrasting massive corals was carried out, in two reefs of the Tayrona National Natural Park (Tayrona NNP), Colombian Caribbean. This to relate the structural complexity of these assemblages with the sediment retention capacity, and to lay the foundations to interpret the conditions in which these turfs advance or recede in the frontier of interaction with the living tissue of the corals that have colonized (Gómez-Cubillos, 2018).

This research contributes to the knowledge about the diversity of algae in the country and presents the first quantitative references on the structure and quantity of sediments retained by algae turfs that grow on coral skeletons in Colombian reefs.

\section{STUDY AREA}

The coral reefs that border the rocky coastline of the Tayrona NNP (Figure 1, $11^{\circ} 12^{\prime}-11^{\circ} 22^{\prime} \mathrm{N}$ and $73^{\circ} 57^{\prime}-$ $74^{\circ} 15^{\prime} \mathrm{W}$ ) are not very wide, of a fringing type, and mainly made up of massive corals. hemispherical. Despite a large number of hard bottoms suitable for the establishment of reefs, the coral formations in this protected area are poorly developed, and their growth is limited compared to other areas of the Colombian Caribbean, due to the strong influence of a climatic regime. Bimodal that oscillates between coastal outcrop during droughts and continental discharges during rains (Zea, 1994). Four climatic seasons 
de la gran cantidad de fondos duros adecuados para el establecimiento de arrecifes, las formaciones coralinas en esta área protegida son poco desarrolladas y su crecimiento es limitado en comparación con otras áreas del Caribe colombiano, debido a la fuerte influencia de un régimen climático bimodal que oscila entre afloramiento costero durante las sequías y descargas continentales durante las lluvias (Zea, 1994). Se distinguen cuatro temporadas climáticas: de afloramiento mayor (diciembre a abril), de no afloramiento menor (mayo a junio), de afloramiento menor o veranillo de San Juan (julio a agosto) y de no afloramiento mayor (septiembre a noviembre) (Bayraktarov y Wild, 2014).

Esta secuencia climática determina la composición algal, especialmente por la proliferación de macroalgas entre enero y abril que luego disminuyen o desaparecen con el incremento de la temperatura del agua entre septiembre y noviembre (Bula-Meyer, 1990), quedando los sustratos duros que no han sido colonizados por macroinvertebrados, recubiertos por céspedes y algas costrosas (Díaz-Pulido y Garzón-Ferreira, 2002).

La historia de perturbación local que han experimentado estos arrecifes en los últimos 50 años ha sido factor clave en los cambios de cobertura coralina (ver compilación en Friedlander et al., 2014) y aumento de la cobertura algal, principalmente de céspedes algales (VegaSequeda et al., 2008), que se estima hayan tenido un aumento anual promedio de 5,6 \% en los últimos 14 años (Acosta et al., 2018) y que en la actualidad son el componente bentónico más abundante ( $>39 \%$ ) y el principal competidor $(58,7 \%)$ por espacio con corales escleractíneos (GómezCubillos et al., 2019).

\section{MATERIALES Y MÉTODOS}

\section{Caracterización estructural de céspedes algales}

Entre noviembre de 2016 y septiembre de 2017 se realizó el seguimiento de la comunidad algal creciendo sobre 120 colonias de corales masivos en dos arrecifes, ubicados en la Ensenada Granate (profundidad 10-16 m) y la bahía de Nenguange (profundidad 4-6 m) (Figura 1; Tabla 1). En cada arrecife se marcaron 20 colonias de cuatro especies de coral morfológicamente contrastantes (Montastraea cavernosa y Pseudodiploria strigosa en ambas estaciones, Stephanocoenia intersepta en Granate y Siderastrea siderea en Nenguange) que tuvieran parte de su esqueleto cubierto por césped, y donde era evidente la are distinguished: major outcrop (December to April), no minor outcrop (May to June), minor outcrop or summer of San Juan (July to August), and no major outcrop (September to November) (Bayraktarov and Wild, 2014).

This climactic sequence determines the algal composition, especially due to the proliferation of macroalgae between January and April, which then decrease or disappear with the increase in water temperature between September and November (Bula-Meyer, 1990), leaving the hard substrates that do not have been colonized by macroinvertebrates, covered by turfs and crusted algae (Díaz-Pulido and Garzón-Ferreira, 2002).

The history of local disturbance that these reefs have experienced in the last 50 years has been a key factor in changes in coral cover (see compilation in Friedlander et al., 2014) and increase in algal cover, mainly of algae turfs (Vega-Sequeda et al., 2008), which are estimated to have had an average annual increase of $5.6 \%$ in the last 14 years (Acosta et al., 2018), and which are currently the most abundant benthic component (> $39 \%$ ) and the main competitor $(58.7 \%$ ) for space with scleractine corals (Gómez-Cubillos et al., 2019).

\section{MATERIALS AND METHODS}

\section{Structural characterization of algal turfs}

Between November 2016 and September 2017, the algal community was monitored growing on 120 massive coral colonies in two reefs, located in Ensenada Granate (depth 10-16 m) and Bay of Nenguange (depth 4-6 m) (Figure 1; Table 1). In each reef, 20 colonies of four morphologically contrasting coral species were marked (Montastraea cavernosa and Pseudodiploria strigosa in both seasons, Stephanocoenia intersepta in Granate, and Siderastrea siderea in Nenguange) that had part of their skeleton covered by turf, and where the presence was evident of active coral-turf interactions (Gómez-Cubillos et al., 2019).

The characterization of the turf assemblages was carried out using the methodology proposed by Connell et al. (2014) and Harris (2015). In the first campaign, near the edge of interaction with living coral tissue, two cores of a coral skeleton covered with turf were extracted per colony, using a hammer and a $27 \mathrm{~mm}$ diameter metal impact punch $\left(5.7 \mathrm{~cm}^{2}\right)$ (Márquez and Zea, 2012). The first core was used to determine the composition and 


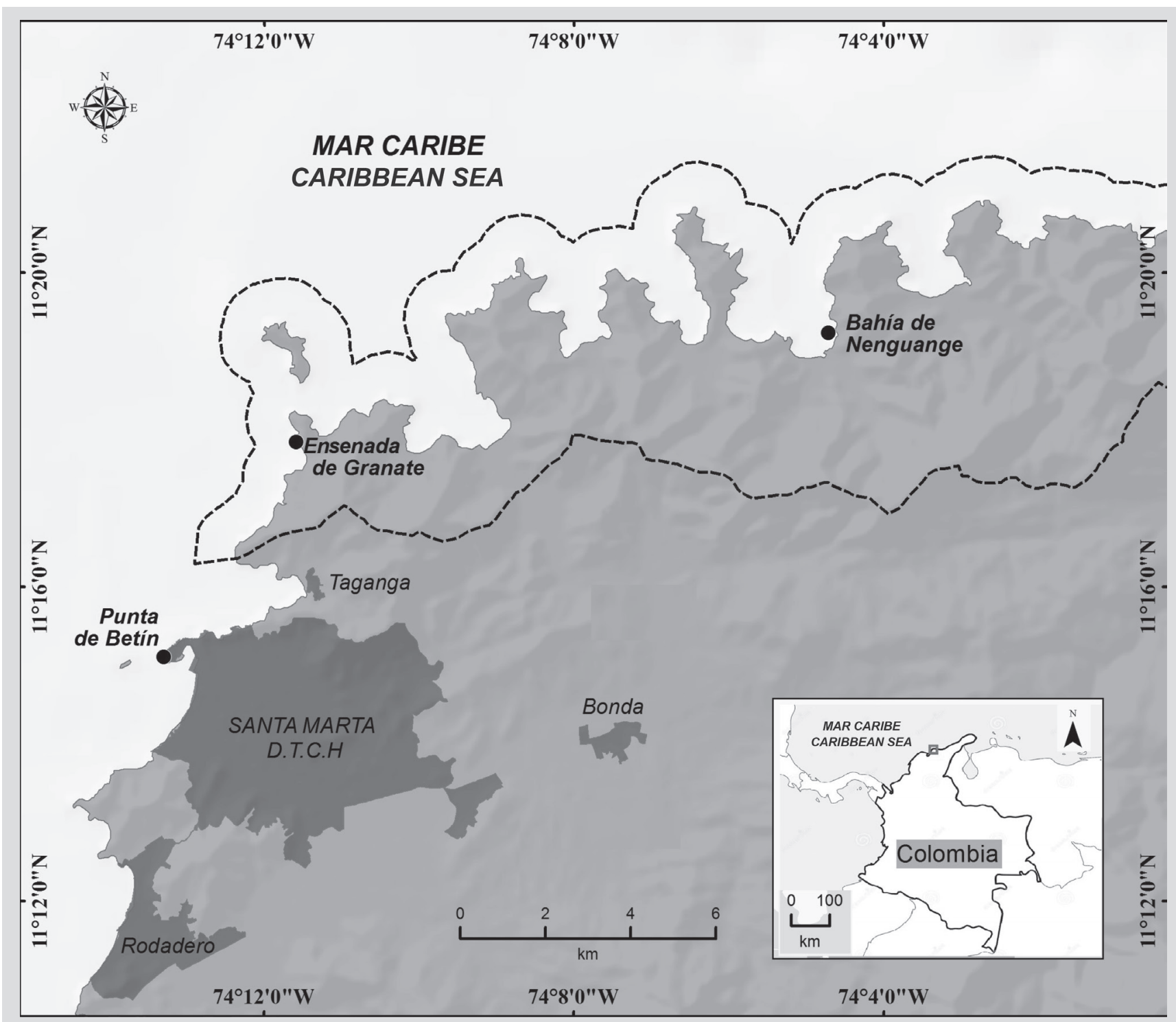

Figura 1. Ubicación de las estaciones en el PNN Tayrona, Caribe colombiano. La línea punteada corresponde al polígono que delimita el área protegida. Fuente: Felipe Valencia, especialista SIG.
Figure 1. Location of the stations in the Tayrona NNP, Colombian Caribbean. The dotted line corresponds to the polygon that delimits the protected area. Source: Felipe Valencia, GIS specialist. presencia de interacciones activas coral-césped (GómezCubillos et al., 2019).

La caracterización de los ensamblajes de céspedes se realizó usando la metodología propuesta por Connell et al. (2014) y Harris (2015). En la primera campaña, cerca del borde de interacción con tejido vivo coralino, por colonia se extrajeron dos núcleos de esqueleto coralino cubierto con césped, empleando un martillo y un sacabocado metálico de impacto de $27 \mathrm{~mm}$ de diámetro $\left(5,7 \mathrm{~cm}^{2}\right.$ ) (Márquez y Zea, 2012). El primer núcleo se empleó para determinar la composición y abundancia por taxón algal, la altura del dosel, la cobertura y la densidad aparente de filamentos, y el segundo núcleo se utilizó para determinar la biomasa algal. abundance by algal taxon, canopy height, cover, and apparent filament density, and the second core was used to determine algal biomass.

In the second campaign, during the macroalgal growth season, the macroalgae present (if any) were manually collected on the coral-turf interaction edges of all the marked colonies. In the last campaign, when the assemblies were made exclusively of turfs, on each interaction edge, a rectangular rubber frame (rim tire) of $4.5 \mathrm{~cm}^{2}$ (3 cm long $\times 1.5 \mathrm{~cm}$ wide, simulating a surgical field), and with a $20 \mathrm{~cm}^{3}$ syringe the sediments accumulated by the turfs in the area delimited by the device were carefully sucked out. 
En la segunda campaña, durante la temporada de proliferación macroalgal, se recolectaron manualmente las macroalgas presentes (si las había) sobre los bordes de interacción coral-césped de todas las colonias marcadas. En la última campaña, cuando los ensamblajes volvieron a ser de céspedes exclusivamente, sobre cada borde de interacción, se ubicó un marco de caucho (neumático de llanta) rectangular de 4,5 $\mathrm{cm}^{2}$ (3 $\mathrm{cm}$ de largo $\times 1,5 \mathrm{~cm}$ de ancho, simulando un campo quirúrgico), y con una jeringa de $20 \mathrm{~cm}^{3}$ se succionaron cuidadosamente los sedimentos acumulados por los céspedes en el área delimitada por el dispositivo.
Turf-extracted cores and macroalgal samples were fixed in $4 \%$ formalin solution in seawater, neutralized with hexamethylene-tetramine $\left(20 . \mathrm{g} \cdot \mathrm{L}^{-1}\right)$, and stored in labeled plastic jars. The contents of the syringes were transferred to $100 \mathrm{ml}$ plastic containers, and the sediments were allowed to settle for $48 \mathrm{~h}$ in distilled water to remove salts, then the excess water was removed and the residue was processed.

To estimate the composition and coverage (\%) by algae species, the samples were wet-checked with a Leica-S6E stereoscope (1.0-4.0 X). By nucleus, coverage

Tabla 1. Cronograma de actividades desarrolladas en campo.

Table 1. Schedule of activities developed in the field.

\begin{tabular}{|c|c|c|c|}
\hline Campaña/Campaign & Fecha/Date & Arrecife/Reef & Procedimiento/Process \\
\hline \multirow{2}{*}{ Primera/First } & Nov-2016 & Granate & \multirow{2}{*}{$\begin{array}{l}\text { Extracción núcleos de esqueleto coralino cubiertos con césped/ } \\
\text { Cores of a coral skeleton covered with turf }\end{array}$} \\
\hline & Feb-2017 & Nenguange & \\
\hline \multirow{2}{*}{ Segunda/Second } & Mar-2017 & Granate & \multirow{2}{*}{$\begin{array}{l}\text { Recolección manual de macroalgas/ } \\
\text { Manual collection of macroalgae }\end{array}$} \\
\hline & May-2017 & Nenguange & \\
\hline Tercera/Third & Sep-2017 & Granate y Nenguange & $\begin{array}{l}\text { Recolección de sedimentos en bordes de interacción coral-césped/ } \\
\text { Sediment collection at the edges of coral-turf interaction }\end{array}$ \\
\hline
\end{tabular}

Los núcleos extraídos con césped y las muestras de macroalgas se fijaron en solución de formalina al $4 \%$ en agua de mar, neutralizada con hexametilén-tetramina $\left(20 . \mathrm{g} \cdot \mathrm{L}^{-1}\right)$, y se almacenaron en tarros plásticos rotulados. El contenido de las jeringas se transvasó a recipientes plásticos de $100 \mathrm{ml}$, y los sedimentos se dejaron decantar durante 48 h en agua destilada para eliminar sales, luego se retiró el exceso de agua y se procesó el residuo.

Para estimar la composición y cobertura (\%) por especie de alga, las muestras se revisaron en húmedo con estereoscopio Leica-S6E (1,0-4,0 X). Por núcleo, se estimó la cobertura (\%) por morfotipo individual, categorizando en incrementos del $5 \%$ (Fricke et al., 2011) respecto al área total del núcleo. De cada morfotipo se preservó una muestra en viales plásticos individuales con formalina al $4 \%$ neutralizada y se tomaron fotografías con microscopio óptico Leica-DM750 con cámara digital MiniVDD-CM500. La mayoría de los morfotipos se identificaron hasta nivel de género empleando las claves taxonómicas de Taylor (1960), Littler y Littler (2000) y Wynne (2011, 2017). Se llegó solo hasta este nivel taxonómico debido al tamaño reducido de
(\%) was estimated by individual morphotype, categorizing in increments of $5 \%$ (Fricke et al., 2011) concerning the total area of the nucleus. A sample of each morphotype was preserved in individual plastic vials with neutralized $4 \%$ formalin, and photographs were taken with a LeicaDM750 optical microscope with a MiniVDD-CM500 digital camera. Most of the morphotypes were identified to the genus level using the taxonomic keys of Taylor (1960), Littler and Littler (2000), and Wynne (2011, 2017). This taxonomic level was only reached due to the reduced size of the filaments and/or the absence of fertile structures or other morphologically important characteristics for their identification at the species level.

To estimate the height of the canopy, it was decided to use a stainless steel ruler with a millimeter scale, and measure three algal filaments at random. The values obtained were averaged to give a single value per core. Then, by the nucleus, the coverage (\%) of the categories of algae turfs, crusted algae, and the bare skeleton was visually estimated (Purcell and Bellwood, 2001), and the apparent density of turf filaments or degree 
los filamentos y/o a la ausencia de estructuras fértiles $\mathrm{u}$ otras características morfológicamente importantes para su identificación a nivel de especie

Para estimar la altura del dosel se decidió usar una regla de acero inoxidable con escala milimétrica, y medir al azar tres filamentos algales. Los valores obtenidos se promediaron para dar un solo valor por núcleo. Luego, por núcleo se estimó visualmente la cobertura (\%) de las categorías céspedes algales, algas costrosas y esqueleto desnudo (Purcell y Bellwood, 2001), y se estimó la densidad aparente de filamentos del césped o grado de agregación de talos y ramas, a partir de las categorías: I) tapetes densamente agregados, con apariencia homogénea, conformados por filamentos cortos $(\sim<2 \mathrm{~mm})$; II) tapetes moderadamente tupidos con filamentos cortos y largos ( 2- $5 \mathrm{~mm})$, y III) tapetes dispersos y altos $(\sim>5 \mathrm{~mm})$ de ramas erectas $\mathrm{y}$ postradas.

Para determinar la biomasa algal, se modificó el método propuesto por Fricke et al. (2011). Cada núcleo se revisó en húmedo empleando estereoscopio (1,02,0 X). Primero se retiraron los organismos diferentes al césped (anélidos, esponjas, algas costrosas, entre otros), y con instrumental de odontología (exploradores, curetas y cucharillas) se rasparon los filamentos del césped. El material obtenido se descalcificó con $\mathrm{HCl} 10 \%$ durante $1 \mathrm{~h}$, y la solución se tamizó (filtros de $180 \mu \mathrm{m}$ y $70 \mu \mathrm{m}$ ) para eliminar restos coralinos y terrígenos. El residuo se pesó con balanza analítica OHAUS-PA313 sobre un filtro de papel previamente pesado. La muestra se mantuvo en estufa por 3 días a $60^{\circ} \mathrm{C}$ y luego se pesó. La biomasa algal $\left(\mathrm{g} \cdot \mathrm{cm}^{-2}\right)$ se calculó dividiendo el valor del peso seco de la muestra entre el área muestreada $\left(5,7 \mathrm{~cm}^{-2}\right)$.

Para determinar la cantidad de sedimentos acumulados por los céspedes, el residuo de los sedimentos obtenidos por decantación se separó en dos fracciones (arenas y limos) empleando un tamiz de $63 \mu \mathrm{m}$. Cada fracción se secó en estufa por 2 días a $105{ }^{\circ} \mathrm{C}$ y se pesó. La cantidad total de sedimentos por muestra y por fracción $\left(\mathrm{g} \cdot \mathrm{cm}^{-2}\right)$ se calculó dividiendo el peso de la muestra seca entre el área muestreada $\left(4,5 \mathrm{~cm}^{-2}\right)$.

Análisis de datos

Las variables evaluadas se caracterizaron con estadística descriptiva y diagramas de cajas y bigotes. Luego para las variables cuantitativas continuas se probaron los supuestos de normalidad (Shapiro-Wilk) y homogeneidad de varianzas (Levene's) (Underwood, 1997). of aggregation of thallus and branches was estimated. From the categories: I) densely aggregated mats, with a homogeneous appearance, made up of short filaments $(\sim<2 \mathrm{~mm})$; II) moderately dense mats with short and long filaments $(\sim 2-5 \mathrm{~mm})$, and III) sparse and tall mats $(\sim>5 \mathrm{~mm})$ of erect and prostrate branches.

To determine the algal biomass, the method proposed by Fricke et al. (2011). Each core was wet-checked using a stereoscope (1.0-2.0 X). First, the organisms other than turf were removed (annelids, sponges, crusted algae, among others), and with dental instruments (explorers, curettes, and teaspoons) the filaments of the turf were scraped. The material obtained was decalcified with $10 \%$ $\mathrm{HCl}$ for $1 \mathrm{~h}$, and the solution was sieved $(180 \mu \mathrm{m}$ and $70 \mu \mathrm{m}$ filters) to remove coral and terrigenous remains. The residue was weighed with an OHAUS-PA313 analytical balance on a previously weighed paper filter. The sample was kept in an oven for 3 days at $60^{\circ} \mathrm{C}$ and then weighed. The algal biomass $\left(\mathrm{g} \cdot \mathrm{cm}^{-2}\right)$ was calculated by dividing the value of the dry weight of the sample by the sampled area $\left(5.7 . \mathrm{cm}^{-}{ }^{2}\right)$.

To determine the amount of sediment accumulated by turfs, the sediment residue obtained by decantation was separated into two fractions (sand and silt) using a $63 \mu \mathrm{m}$ sieve. Each fraction was dried in an oven for 2 days at $105^{\circ} \mathrm{C}$ and weighed. The total amount of sediment per sample and per fraction $\left(\mathrm{g} \cdot \mathrm{cm}^{-2}\right)$ was calculated by dividing the weight of the dry sample by the sampled area $\left(4.5 \mathrm{~cm}^{-2}\right)$.

\section{Analysis of data}

The variables evaluated were characterized by descriptive statistics and box-and-whisker diagrams. Then, for the continuous quantitative variables, the assumptions of normality (Shapiro-Wilk) and homogeneity of variances (Levene's) (Underwood, 1997) were tested.

By reef and type of substrate (coral species), a matrix was made with the frequency (percentage relationship between the number of times the morphotype is recorded and the total number of nuclei per coral species evaluated) and coverage (\%) of the genera of Identified turf algae. The coverage data were transformed using the arcsine formula (Sokal and Rohlf, 1981).

To establish differences in the composition of turf assemblages between reefs and substrates, with the transformed coverage matrix and the Bray-Curtis similarity 
Por arrecife y tipo de sustrato (especie de coral) se elaboró una matriz con la frecuencia (relación porcentual entre el número de veces que se registra el morfotipo y el total de núcleos por especie coralina evaluados) y cobertura (\%) de los géneros de algas del césped identificados. Los datos de cobertura se transformaron empleando la fórmula de arcoseno (Sokal y Rohlf, 1981).

Para establecer diferencias en la composición de los ensamblajes de céspedes entre arrecifes y sustratos, con la matriz de cobertura transformada y el índice de similaridad de Bray-Curtis se realizó un Análisis de Similitud (ANOSIM) a dos vías y un Análisis de Porcentaje de Similitud (SIMPER) (Clarke y Warwick, 2001), empleando el programa Primer 6 versión 6.1 .13 a un nivel de confianza del $95 \%$.

Mediante pruebas no paramétricas de MannWhitney (M-WU), Kruskal-Wallis (K-W) y post-hoc (Agresti, 2002) se determinaron diferencias estadísticas entre arrecifes y sustratos respecto a la altura del dosel, biomasa algal y cantidad total de sedimentos acumulados. Con tablas de contingencia y pruebas de independencia de $\mathrm{Chi}^{2}$ (Sokal y Rohlf, 1981) se identificó la asociación entre el arrecife y el sustrato con las variables expresadas en porcentajes (cobertura por categorías, densidad de filamentos y fracción de sedimentos).

Empleando correlaciones de Spearman (González y Pérez, 2009), se identificó de manera general y por arrecife, la interdependencia entre la cantidad total y por fracción de sedimentos acumulados en bordes de interacción coral-césped con las variables cobertura (\%) por taxa, altura de dosel y biomasa algal. Los análisis se realizaron con el programa Statgraphics Centurion XVI versión 16.1.18. a un nivel de confianza del $95 \%$.

\section{RESULTADOS}

\section{Composición, presencia de taxa diagnósticos}

y persistencia del ensamblaje

Se identificaron 30 taxa a nivel de género, pertenecientes a 13 órdenes y 18 familias (Tabla 2). Las Rhodophyta fueron las algas más diversas (20 géneros), seguidas por las Chlorophyta (cinco géneros), las Phaeophyceae (cuatro géneros) y las cianobacterias (un género y tres morfotipos). Además, se registró la presencia de los géneros Anotrichium y Corallophila, taxa reconocidos como perjudiciales para los corales (Díaz-Pulido y McCook, 2002; Jompa y McCook, 2003b). index, a two-way Analysis of Similarity (ANOSIM) and a Percentage of Similarity Analysis (SIMPER) were performed (Clarke and Warwick, 2001), using the Primer 6 version 6.1 .13 program at a $95 \%$ confidence level.

Utilizing non-parametric tests of Mann-Whitney (M-WU), Kruskal-Wallis (KW), and posthoc (Agresti, 2002) statistical differences between reefs and substrates were determined regarding the height of the canopy, algal biomass, and total amount of accumulated sediment. With contingency tables and $\mathrm{Chi}^{2}$ independence tests (Sokal and Rohlf, 1981) the association between the reef and the substrate was identified with the variables expressed in percentages (coverage by categories, the density of filaments, and a fraction of sediments).

Using Spearman correlations (González and Pérez, 2009), the interdependence between the total amount and the fraction of accumulated sediments on the edges of coral-turf interaction was identified in a general way and by a reef, with the variables coverage (\%) by taxa, canopy height, and algal biomass. The analyzes were performed with the Statgraphics Centurion XVI program version 16.1.18. at a $95 \%$ confidence level.

\section{RESULTS}

Composition, presence of diagnostic taxa, and persistence of the assembly

Thirty taxa were identified at the genus level, belonging to 13 orders and 18 families (Table $2)$. The Rhodophyta were the most diverse algae ( 20 genera), followed by the Chlorophyta (five genera), the Phaeophyceae (four genera), and the cyanobacteria (one genus and three morphotypes). Also, the presence of the Anotrichium and Corallophila genera, taxa recognized as harmful to corals, was recorded (Díaz-Pulido and McCook, 2002; Jompa and McCook, 2003b).

In Granate, the turfs were composed of 23 genera (Table 2). In all substrates or coral skeletons, Amphiroa and Gelidium were the most frequent genera, and in $61 \%$ of the skeletons of $S$. intersepta the genus Dictyota was found. The genera Corallophila, Taenioma, and Chaetomorpha were not recorded on this reef (Figure 2A).

In Nenguange, the turfs were made up of 24 genera (Table 2). In general, Polysiphonia, Chondria, 
En Granate, los céspedes estuvieron compuestos por 23 géneros (Tabla 2). En todos los sustratos o esqueletos de coral, Amphiroa y Gelidium fueron los géneros más frecuentes, y en el $61 \%$ de los esqueletos de $S$. intersepta se encontró el género Dictyota. En este arrecife no se registraron los géneros Corallophila, Taenioma y Chaetomorpha (Figura 2A).

En Nenguange, los céspedes estuvieron conformados por 24 géneros (Tabla 2). En general, Polysiphonia, Chondria y Herposiphonia fueron los géneros más frecuentes en los tres tipos de sustratos. Adicionalmente, sobre esqueletos de M. cavernosa, los géneros Ceramium, Sphacelaria, Cladophora y Gelidium, y sobre esqueletos de $P$. strigosa, los géneros Amphiroa y Gelidiopsis registraron una frecuencia superior al $50 \%$. En este arrecife no se registraron los géneros Parviphycus y Dictyota (Figura 2B).

Tabla 2. Listado taxonómico de géneros y posibles especies [identificación tentativa] que conforman los ensamblajes de algas que interactúan con tejido vivo de corales masivos en arrecifes del PNN Tayrona, Caribe colombiano. En cada arrecife la primera fecha corresponde a céspedes algales (núcleos de esqueleto coralino) y la segunda a macroalgas que recubrían los bordes de interacción durante le época de florecimiento macroalgal. ${ }^{\dagger}$ Taxa ya registrados en el PNN Tayrona por Díaz-Pulido y Díaz-Ruíz, 2003. ' Presencia estructuras reproductivas. and Herposiphonia were the most frequent genera in the three types of substrates. Additionally, on skeletons of M. cavernosa, the genera Ceramium, Sphacelaria, Cladophora, and Gelidium, and skeletons of P. strigose, the genera Amphiroa and Gelidiopsis registered a frequency higher than $50 \%$. The genera Parviphycus and Dictyota were not recorded on this reef (Figure 2B).

ANOSIM showed that between reefs there are differences in the coverage (\%) of the genera that make up the assemblages of turf (nuclei), but with overlapping groups $\left(\mathrm{R}_{\text {global }}=0.46\right.$; significance level $0.1 \%$ ), while There are no statistical differences between substrates $\left(\mathrm{R}_{\text {global }}=0.12\right.$; significance level $\left.0.1 \%\right)$.

Table 2. Taxonomic list of genera and possible species [tentative identification] that make up the assemblages of algae that interact with the living tissue of massive corals in reefs of the Tayrona NNP, Colombian Caribbean. In each reef, the first date corresponds to algae turfs (coralline skeleton nuclei), and the second to macroalgae that covered the interaction edges during the macroalgal flowering season. ${ }^{\dagger}$ Tax already registered in the Tayrona PNN by Díaz-Pulido and Díaz-Ruíz, 2003. ${ }^{\star}$ Presence of reproductive structures.

\begin{tabular}{|c|c|c|c|c|}
\hline \multirow{3}{*}{ Taxa } & \multicolumn{4}{|c|}{ Arrecife/Fecha / Reef/Date } \\
\hline & \multicolumn{2}{|c|}{ Granate } & \multicolumn{2}{|c|}{ Nenguange } \\
\hline & Nov-16 & Mar-17 & Feb-17 & May-17 \\
\hline \multicolumn{5}{|l|}{ Cyanophyceae } \\
\hline \multicolumn{5}{|l|}{ Oscillatoriales } \\
\hline \multicolumn{5}{|l|}{ Oscillatoriaceae } \\
\hline Lyngbya $\mathrm{sp}^{\dagger}$ & $\mathrm{X}$ & & $\mathrm{X}$ & \\
\hline Otras cianobacterias & $\mathrm{X}$ & & $\mathrm{X}$ & \\
\hline \multicolumn{5}{|l|}{ Rhodophyceae } \\
\hline \multicolumn{5}{|l|}{ Corallinales } \\
\hline \multicolumn{5}{|l|}{ Lithophyllaceae } \\
\hline Amphiroa $\mathrm{sp}^{\dagger}$ & $\mathrm{X}$ & $\mathrm{X}$ & $\mathrm{X}$ & $\mathrm{X}$ \\
\hline \multicolumn{5}{|l|}{ Gelidiales } \\
\hline \multicolumn{5}{|l|}{ Gelidiellaceae } \\
\hline Gelidium sp1 [Gelidium cf. americanum (W.R.Taylor) Santelices ${ }^{\dagger}$ ] & $\mathrm{X}$ & & $\mathrm{X}$ & \\
\hline Gelidium sp2 [Gelidium cf. pusillum (Stackhouse) LeJolis ${ }^{\dagger}$ ] & $\mathrm{X}$ & & & \\
\hline Parviphycus sp1 & $\mathrm{X}$ & & & \\
\hline
\end{tabular}


Taxa

\section{Arrecife/Fecha / Reef/Date}

\begin{tabular}{|c|c|c|c|}
\hline \multicolumn{2}{|c|}{ Granate } & \multicolumn{2}{c|}{ Nenguange } \\
\hline Nov-16 & Mar-17 & Feb-17 & May-17 \\
\hline
\end{tabular}

Parviphycus sp2

$\mathrm{X}$

Gelidiella sp ${ }^{\dagger}$

X

X

Pterocladiaceae

Pterocladiella sp1

X

$\mathrm{X}$

Nemaliales

Galaxauraceae

Galaxaura sp

$\mathrm{X}$

Rhodymeniales

Champiaceae

Champia sp

$\mathrm{X}$

Lomentariaceae

Ceratodictyon $\mathrm{sp}$

Ceratodictyon sp1 [Ceratodictyon cf. variabile (J.Agardh) R.E.Norris ${ }^{\dagger}$ ]

$\mathrm{X} \quad \mathrm{X}$

$\mathrm{X}$

$\mathrm{X}$

Ceratodictyon $\mathrm{sp} 2$ [Ceratodictyon cf. scoparium (Montagne \& Millardet) R.E.Norris ${ }^{\dagger}$ ]

$\mathrm{X}$

Ceratodictyon sp3 [Ceratodictyon cf. planicaule (W.R.Taylor) M.J.Wynne ${ }^{\dagger}$ ]

$\mathrm{X}$

Ceramiales

Ceramiaceae

Ceramium $\mathrm{sp}^{\dagger}$

$\mathrm{X}$

$\mathrm{X}$

X

Corallophila $\mathrm{sp}$

X

Wrangeliaceae

Anotrichium sp. [Anotrichium cf. tenue (C.Agardh) Nägeli ${ }^{\dagger}$ ]

Griffithsia sp. [Griffithsia cf. schousboei Montagne ${ }^{\dagger}$ ]

Lejolisia sp.

Delesseriaceae

Martensia sp.

X

Rhodomelaceae

Chondria $\mathrm{sp} 1$

Chondria $\mathrm{sp} 2$

$\mathrm{X}^{\ddagger}$

$\mathrm{X}$

$\mathrm{X}^{\ddagger}$

Chondria $\mathrm{sp} 3$

Herposiphonia sp.

Melanothamnus sp.

Polysiphonia sp1 [Polysiphonia cf. howei Hollenberg ${ }^{\dagger}$ ]

Polysiphonia $\mathrm{sp} 2$

\begin{tabular}{c|c|c}
\hline$X$ & $X$ & $X$ \\
\hline$X^{\ddagger}$ & $X$ & $X$ \\
\hline$X$ & & $X$
\end{tabular}

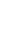




\begin{tabular}{|c|c|c|c|c|}
\hline \multirow{3}{*}{ Taxa } & \multicolumn{4}{|c|}{ Arrecife/Fecha / Reef/Date } \\
\hline & \multicolumn{2}{|c|}{ Granate } & \multicolumn{2}{|c|}{ Nenguange } \\
\hline & Nov-16 & Mar-17 & Feb-17 & May-17 \\
\hline \multicolumn{5}{|l|}{ Delesseriaceae } \\
\hline Taenioma $\mathrm{sp}^{\dagger}$ & & & $\mathrm{X}$ & \\
\hline \multicolumn{5}{|l|}{ Phaeophyceae } \\
\hline \multicolumn{5}{|l|}{ Ectocarpales } \\
\hline \multicolumn{5}{|l|}{ Ectocarpaceae } \\
\hline Ectocarpus sp ${ }^{\dagger}$ & $\mathrm{X}$ & & $\mathrm{X}$ & \\
\hline \multicolumn{5}{|l|}{ Sphacelariales } \\
\hline \multicolumn{5}{|l|}{ Sphacelariaceae } \\
\hline Sphacelaria sp1 [Sphacelaria cf. rigidula Kützing ${ }^{\dagger}$ ] & $\mathrm{X}$ & & $\mathrm{X}$ & \\
\hline Sphacelaria $\mathrm{sp}^{\dagger}$ & $\mathrm{X}$ & & $\mathrm{X}$ & \\
\hline \multicolumn{5}{|l|}{ Dictyotales } \\
\hline \multicolumn{5}{|l|}{ Dictyotaceae } \\
\hline Dictyota $\mathrm{sp} 1^{\dagger}$ & $\mathrm{X}^{\ddagger}$ & & & \\
\hline Dictyota sp2 & & $X$ & & \\
\hline Dictyota sp3 [Dictyota cf. bartayresiana J.V.Lamouroux ${ }^{\dagger}$ ] & & $\mathrm{X}$ & & \\
\hline Dictyota sp4 & & $\mathrm{X}$ & & $\mathrm{X}$ \\
\hline Dictyota sp5 [Dictyota cf. hamifera Setchell $\left.{ }^{\dagger}\right]$ & & $\mathrm{X}$ & & \\
\hline \multicolumn{5}{|l|}{ Fucales } \\
\hline \multicolumn{5}{|l|}{ Sargassaceae } \\
\hline Sargassum $\mathrm{sp}^{\dagger}$ & & $\mathrm{X}$ & & \\
\hline \multicolumn{5}{|l|}{ Chlorophyceae } \\
\hline \multicolumn{5}{|l|}{ Ulvales } \\
\hline \multicolumn{5}{|l|}{ Ulvaceae } \\
\hline Ulva sp. [Ulva cf. flexuosa Wulfen ${ }^{\dagger}$ ] & $\mathrm{X}$ & $\mathrm{X}$ & $\mathrm{X}$ & \\
\hline \multicolumn{5}{|l|}{ Cladophorales } \\
\hline \multicolumn{5}{|l|}{ Cladophoraceae } \\
\hline Cladophora sp. & $\mathrm{X}$ & $\mathrm{X}$ & $\mathrm{X}$ & \\
\hline Bryobesia sp. & & $\mathrm{X}$ & & \\
\hline Chaetomorpha $\mathrm{sp}^{\dagger}$ & & & $\mathrm{X}$ & \\
\hline \multicolumn{5}{|l|}{ Bryopsidales } \\
\hline \multicolumn{5}{|l|}{ Bryopsidaceae } \\
\hline Bryopsis sp ${ }^{\dagger}$ & $\mathrm{X}$ & & $\mathrm{X}$ & \\
\hline
\end{tabular}




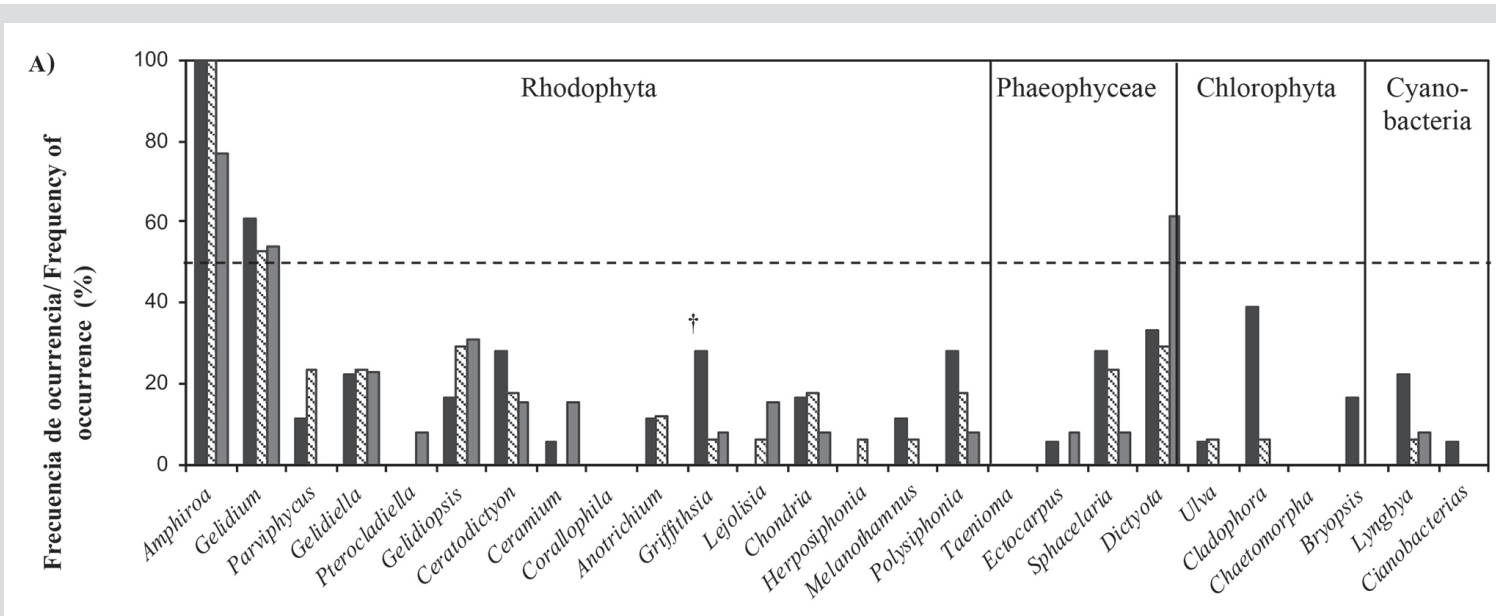

M. cavernosa

因P. strigosa

$\square$ S. intersepta

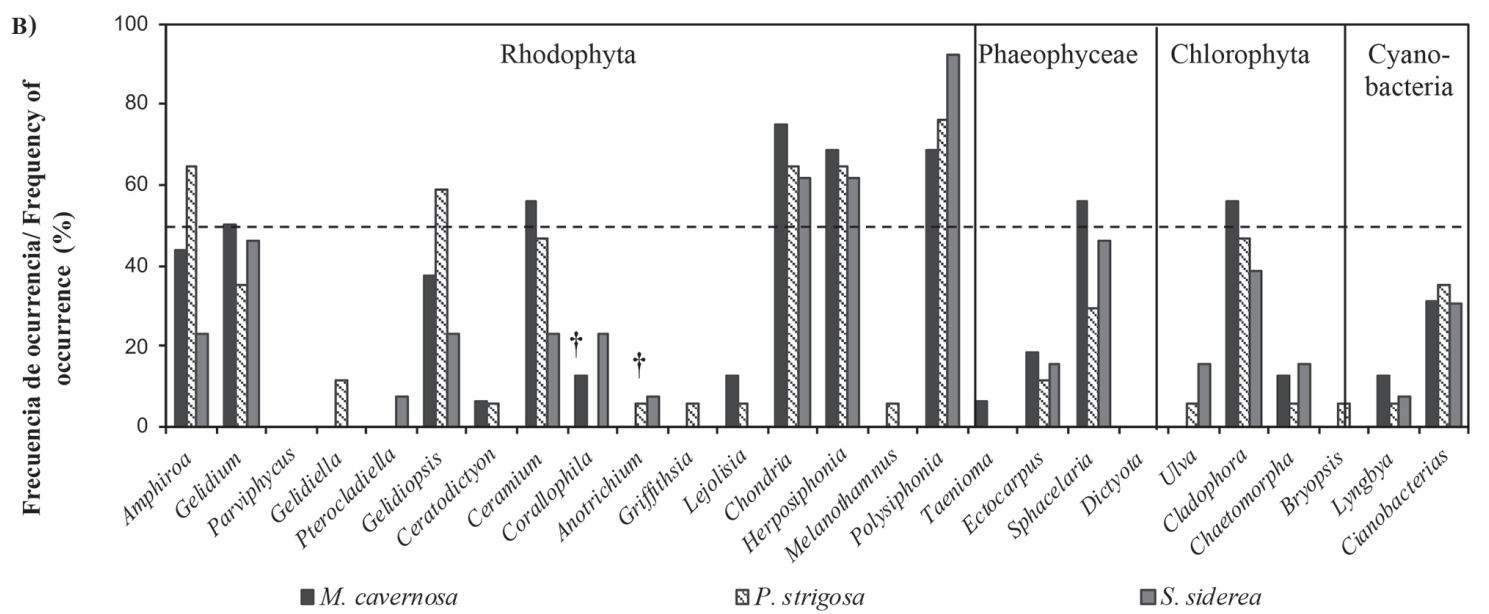

C)

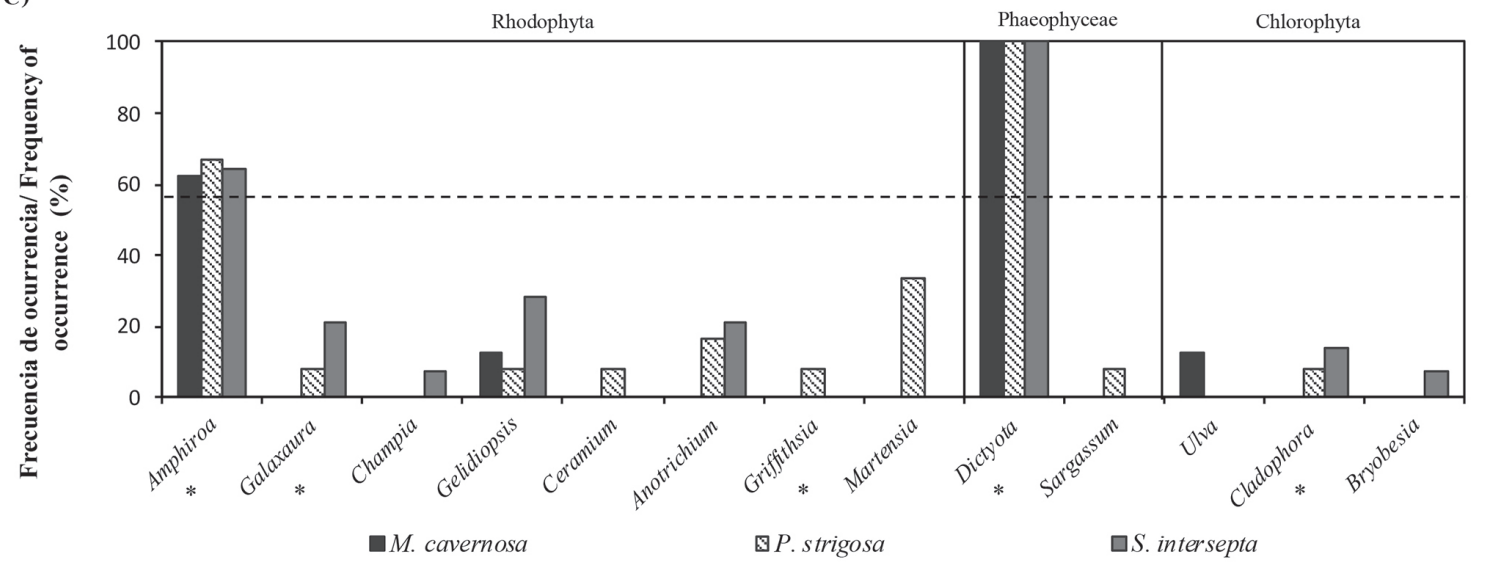

Figura 2. Frecuencia de ocurrencia (\%) de los géneros que componen los ensamblajes algales que crecen sobre esqueletos de coral, en los arrecifes A) Granate ( $\mathrm{n}=48$ colonias; nov de 2016); B) Nenguange ( $\mathrm{n}=46$; feb de 2017) y C) Granate ( $\mathrm{n}=33$; mar de 2017). A) y B) corresponden a los céspedes encontrados en los núcleos, y C) a las macroalgas recolectadas manualmente que recubrían los bordes de interacción durante el florecimiento macroalgal (Nenguange no se incluye porque el florecimiento macroalgal allí fue mínimo). Las cruces (†) indican taxa reconocidos como perjudiciales para los corales y los asteriscos $(*)$ los géneros encontrados solamente durante el florecimiento macroalgal. La línea punteada representa el corte de la frecuencia al $50 \%$.
Figure 2. Frequency of occurrence (\%) of the genera that make up the algal assemblages that grow on coral skeletons, in the reefs A) Garnet $(\mathrm{n}=48$ colonies; Nov 2016); B) Nenguange ( $\mathrm{n}=46$; Feb 2017) and C) Garnet ( $\mathrm{n}=33$; Mar 2017). A) and B) correspond to the turfs found in the cores, and C) to the manually collected macroalgae that covered the interaction edges during the macroalgal bloom (Nenguange is not included because the macroalgal bloom there was minimal). The crosses $(\dagger)$ indicate taxa recognized as damaging to corals and the asterisks (*) the genera found only during macroalgal bloom. The dotted line represents the frequency cutoff at $50 \%$. 
El ANOSIM mostró que entre arrecifes existen diferencias en la cobertura (\%) de los géneros que componen los ensamblajes de céspedes (núcleos), pero con superposición de grupos $\left(\mathrm{R}_{\text {global }}=0,46\right.$; nivel de significancia $0,1 \%$ ), mientras que entre sustratos no existen diferencias estadísticas $\left(\mathrm{R}_{\text {global }}=0,12\right.$; nivel de significancia $\left.0,1 \%\right)$.

El SIMPER por arrecife (Tabla 3) mostró que en Granate los ensamblajes de céspedes estuvieron conformados en más del $80 \%$ por algas foliáceas (Dictyota), erectas corticadas (Gelidiales) y calcáreas articuladas (Amphiroa), pero de tamaño pequeño (Figura 2A). Por el contrario, en Nenguange el principal aporte lo hicieron algas filamentosas (Polysiphonia, Herposiphonia y Sphacelaria) y pequeñas erectas corticadas (Chondria y Gelidiales) (Figura 2B). Además, se identificó que 10 géneros contribuyeron con más de $50 \%$ de la disimilitud entre estaciones (Tabla 3).

Tabla 3. Géneros de algas del césped que definen la similitud dentro y disimilitud entre estaciones. Resultados obtenidos del SIMPER. Convenciones: $\mathrm{AP}=$ abundancia promedio. $\mathrm{SP}=$ similitud promedio. $\mathrm{Sim}=$ Similitud $\mathrm{SD}=$ Desviación estándar. $\mathrm{CTB}=$ Contribución porcentual. $\mathrm{ACM}=$ Porcentaje acumulado.
The SIMPER per reef (Table 3), showed that in Granate the turf assemblages were made up of more than $80 \%$ of foliaceous (Dictyota), erect corticated (Gelidiales), and articulated calcareous (Amphiroa) algae, but of small size (Figure 2A). On the contrary, in Nenguange the main contribution was made by filamentous algae (Polysiphonia, Herposiphonia, and Sphacelaria) and small erect corticates (Chondria and Gelidiales) (Figure 2B). Also, it was identified that 10 genera contributed more than $50 \%$ of the dissimilarity between stations (Table 3).

In 2017, during and immediately after the months of the coastal outcrop (March to May), when a visual inspection of the marked colonies was made and the macroalgae that covered the interface with living coral tissue were manually collected, only in Granate a transition from turfs to macroalgae beds. This new assemblage in

Table 3. Turf algae genera that define similarity within and dissimilarity between seasons. Results obtained from SIMPER. Conventions: AP = average abundance. $\mathrm{SP}=$ average similarity. $\mathrm{Sim}=$ Similarity. $\mathrm{SD}=$ Standard deviation. $\mathrm{CTB}=$ Percentage contribution. $\mathrm{ACM}=$ Accumulated percentage.

\begin{tabular}{|c|c|c|c|c|c|}
\hline & $\mathbf{A P}$ & SP & Sim/SD & СТВ \% & ACM \% \\
\hline \multicolumn{6}{|c|}{ Similitud dentro de los arrecifes/Similarity within reefs } \\
\hline \multicolumn{6}{|c|}{ Granate $(30.46 \%)$} \\
\hline Amphiroa & 23.95 & 15.22 & 1.83 & 49.98 & 49.98 \\
\hline Gelidium & 18.98 & 6.70 & 0.60 & 21.99 & 71.97 \\
\hline Dictyota & 10.57 & 2.53 & 0.40 & 8.31 & 80.28 \\
\hline Gelidiella & 9.27 & 1.26 & 0.20 & 4.13 & 84.41 \\
\hline Gelidiopsis & 8.33 & 1.20 & 0.23 & 3.94 & 88.35 \\
\hline Ceratodictyon & 7.68 & 1.00 & 0.18 & 3.27 & 91.63 \\
\hline \multicolumn{6}{|c|}{ Nenguange (38.86 \%) } \\
\hline Polysiphonia & 23.88 & 10.83 & 1.09 & 27.87 & 27.87 \\
\hline Chondria & 15.37 & 6.05 & 0.86 & 15.57 & 43.44 \\
\hline Herposiphonia & 13.68 & 5.11 & 0.80 & 13.15 & 56.60 \\
\hline Sphacelaria & 12.69 & 2.80 & 0.43 & 7.20 & 63.80 \\
\hline Gelidiopsis & 11.15 & 2.75 & 0.43 & 7.08 & 70.87 \\
\hline Gelidium & 10.11 & 2.58 & 0.46 & 6.65 & 77.53 \\
\hline Cladophora & 8.83 & 2.45 & 0.52 & 6.30 & 83.83 \\
\hline Amphiroa & 8.98 & 2.31 & 0.48 & 5.94 & 89.77 \\
\hline Ceramium & 8.88 & 2.16 & 0.46 & 5.57 & 95.33 \\
\hline
\end{tabular}




\begin{tabular}{|c|c|c|c|c|c|c|}
\hline & \multicolumn{2}{|c|}{$\mathbf{A P}$} & SP & $\mathbf{S i m} / \mathbf{S D}$ & СТВ \% & ACM \% \\
\hline \multicolumn{7}{|c|}{ Dissimilarity between reefs $(80.94 \%)$} \\
\hline & Granate & Nenguange & & & & \\
\hline Polysiphonia & 5.02 & 23.88 & 9.17 & 1.33 & 11.33 & 11.33 \\
\hline Gelidium & 18.98 & 10.11 & 7.48 & 1.07 & 9.24 & 20.57 \\
\hline Amphiroa & 23.95 & 8.98 & 7.26 & 1.38 & 8.97 & 29.54 \\
\hline Gelidiopsis & 8.33 & 11.15 & 5.87 & 0.89 & 7.25 & 36.79 \\
\hline Chondria & 2.88 & 15.37 & 5.75 & 1.22 & 7.11 & 43.90 \\
\hline Sphacelaria & 5.62 & 12.69 & 5.71 & 0.80 & 7.05 & 50.95 \\
\hline Herposiphonia & 0.27 & 13.68 & 5.33 & 1.16 & 6.59 & 57.54 \\
\hline Dictyota & 10.57 & 0.00 & 4.19 & 0.66 & 5.18 & 62.72 \\
\hline Gelidiella & 9.27 & 1.38 & 4.18 & 0.50 & 5.16 & 67.87 \\
\hline Cladophora & 3.27 & 8.83 & 3.77 & 0.86 & 4.66 & 72.53 \\
\hline Ceramium & 1.04 & 8.88 & 3.57 & 0.73 & 4.41 & 76.94 \\
\hline Ceratodictyon & 7.68 & 1.23 & 3.43 & 0.50 & 4.24 & 81.18 \\
\hline Cianobacterias & 0.27 & 6.28 & 2.47 & 0.66 & 3.05 & 84.23 \\
\hline Parviphycus & 4.32 & 0.00 & 1.68 & 0.33 & 2.07 & 86.31 \\
\hline Ectocarpus & 0.94 & 3.31 & 1.58 & 0.43 & 1.96 & 88.27 \\
\hline Malanothamnus & 3.36 & 0.40 & 1.53 & 0.26 & 1.89 & 90.16 \\
\hline
\end{tabular}

En 2017, durante e inmediatamente después de los meses de afloramiento costero (marzo a mayo), cuando se realizó una inspección visual de las colonias marcadas y se recolectaron manualmente las macroalgas que recubrían la interface con tejido vivo coralino, solo en Granate se evidenció una transición de céspedes a lechos de macroalgas. Este nuevo ensamblaje en Granate estuvo conformado por 13 taxa (Tabla 2), de los cuales 8 géneros ya se habían encontrado en las muestras del césped, pero ahora con crecimiento frondoso; se registraron cinco géneros adicionales (Galaxaura, Champia, Martensia, Sargassum y Bryobesia), y se confirmó que Dictyota y Amphiroa son los géneros dominantes (Figura 2C). Se aclara que en septiembre de 2017 estas macroalgas desaparecieron, volviendo a dominar los céspedes algales (que no se cuantificaron nuevamente). En Nenguange, en cambio, solo una colonia de $P$. strigosa fue colonizada por macroalgas en mayo de 2017, siendo los céspedes el ensamblaje dominante durante todo el periodo de investigación (febrero a septiembre de 2017).
Granate consisted of 13 taxa (Table 2), of which 8 genera had already been found in the turf samples, but now with bushy growth; five additional genera were recorded (Galaxaura, Champia, Martensia, Sargassum, and Bryobesia), and Dictyota and Amphiroa were confirmed to be the dominant genera (Figure 2C). It is clarified that in September 2017 these macroalgae disappeared, re-dominating the algal turfs (which were not quantified again). In Nenguange, on the other hand, only one colony of P. strigosa was colonized by macroalgae in May 2017, with turfs being the dominant assemblage throughout the research period (February to September 2017).

\section{Canopy height}

No significant differences were found in canopy height between reefs $\left(\mathrm{M}-\mathrm{W} \mathrm{U}=8575.0 ; \mathrm{n}_{\text {Granate }}=144\right.$; $\mathrm{n}_{\text {Nenguange }}=138 ; \mathrm{P}<0.05$ ). In Granate the average height of the turf was $5.1 \pm 0.20 \mathrm{~mm}$ (variations between 2.0 and $16.0 \mathrm{~mm}$ ), and in Nenguange it was $4.5 \pm 0.17 \mathrm{~mm}$ (variations between 1.0 and $12.0 \mathrm{~mm}$ ). 
Altura del dosel

No se encontraron diferencias significativas en la altura del dosel entre arrecifes $(\mathrm{M}-\mathrm{W} \mathrm{U}=8575,0$; $\left.\mathrm{n}_{\text {Granate }}=144 ; \mathrm{n}_{\text {Nenguange }}=138 ; \mathrm{P}<0,05\right)$. En Granate la altura promedio del césped fue de 5,1 $\pm 0,20 \mathrm{~mm}$ (variaciones entre 2,0 y 16,0 mm), y en Nenguange de 4,5 $\pm 0,17 \mathrm{~mm}$ (variaciones entre 1,0 y 12,0 mm).

Según los sustratos, en Granate no se encontraron diferencias $(\mathrm{K}-\mathrm{W}=0,6 ; \mathrm{P}>0,05)$, pero en Nenguange sí ( $\mathrm{K}-\mathrm{W}=14,1 ; \mathrm{P}<0,05)$, ya que los céspedes sobre esqueletos de $P$. strigosa fueron estadísticamente más altos que sobre esqueletos de $M$. cavernosa y $S$. siderea (Figura 3).
According to the substrates, in Granate, no differences were found $(\mathrm{KW}=0.6 ; \mathrm{P}>0.05)$, but in Nenguange there were $(\mathrm{KW}=14.1 ; \mathrm{P}<0.05)$, since the turfs on skeletons $P$. strigosa were statistically higher than on skeletons of $M$. cavernosa and $S$. siderea (Figure 3).

\section{Coverage and apparent density of filaments}

In general, the percentage of coverage in the cores of the three categories defined a priori (algae turfs, crusted algae and bare skeleton) varied between reefs $\left(\mathrm{Chi}^{2}=6061.5 ; \mathrm{P}<0.05 ; \mathrm{GL}=186\right)$ and between substrates (Granate: $\mathrm{Chi}^{2}=3110.4 ; \mathrm{P}<0.05 ; \mathrm{GL}=94$ and Nenguange: $\left.\mathrm{Chi}^{2}=1888.8 ; \mathrm{P}<0.05 ; \mathrm{GL}=90\right)$.

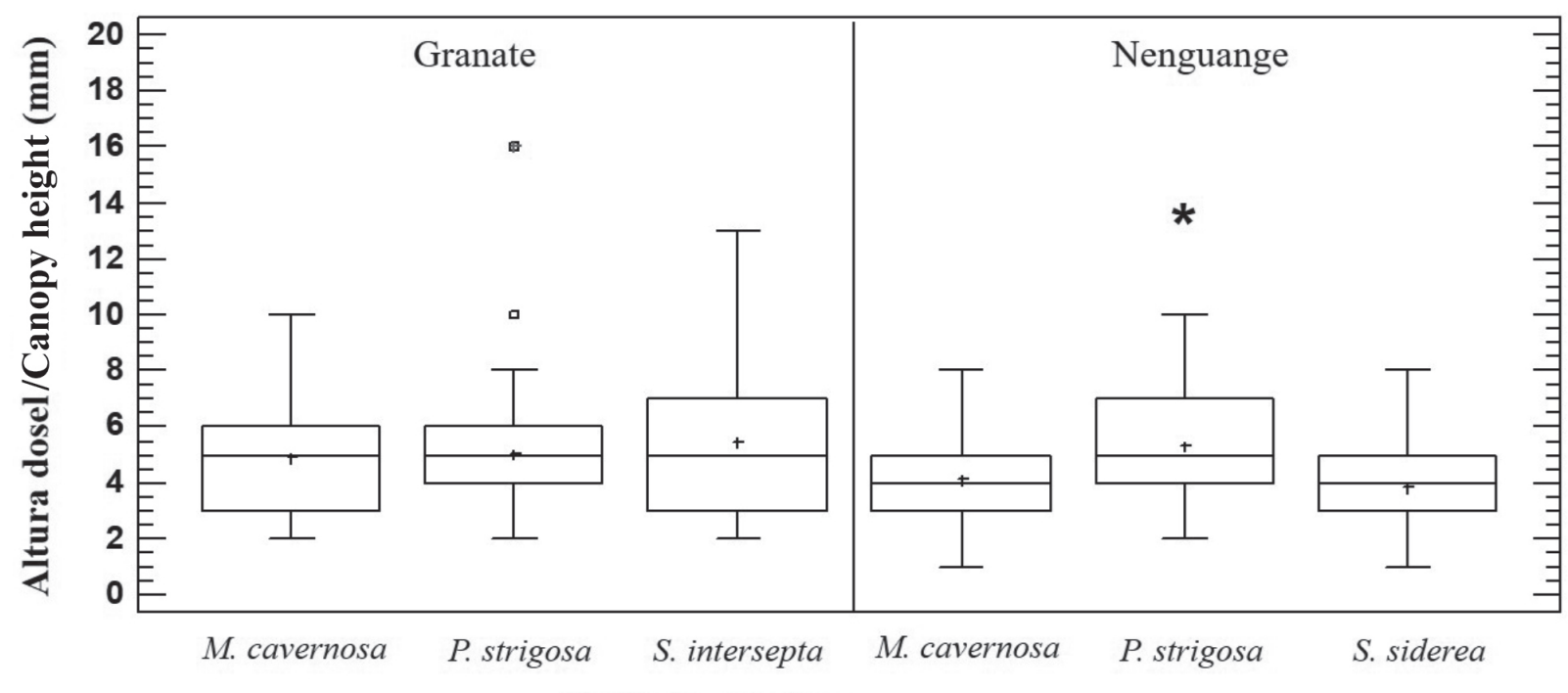

\section{Sustrato coralino/Coral substrate}

Figura 3. Altura del dosel ( $\mathrm{mm})$ de los céspedes que crecen sobre esqueletos coralinos en porciones adyacentes a interacciones con tejido vivo coralino, en los arrecifes de Granate y Nenguange (PNN Tayrona). Las barras horizontales indican las medianas, las cajas el primer y tercer cuartil, los bigotes el rango de datos, la cruz $(+)$ el promedio, los cuadrados los valores extremos y el asterisco $(*)$ indica cual sustrato tuvo promedio significativamente diferente.
Figure 3. Canopy height $(\mathrm{mm})$ of turfs growing on coral skeletons in portions adjacent to interactions with living coral tissue, in the Granate and Nenguange reefs (PNN Tayrona). The horizontal bars indicate the medians, the boxes the first and third quartiles, the whiskers the data range, the cross $(+)$ the average, the squares the extreme values, and the asterisk $(*)$ indicates which substrate had a significantly different average.

\section{Cobertura y densidad aparente de filamentos}

En general, el porcentaje de cobertura en los núcleos de las tres categorías definidas a priori (céspedes algales, algas costrosas y esqueleto desnudo) varió entre arrecifes $\left(\mathrm{Chi}^{2}=6061,5 ; \mathrm{P}<0,05 ; \mathrm{GL}=186\right)$ y entre sustratos (Granate: $\mathrm{Chi}^{2}=3110,4$; $\mathrm{P}<0,05$; GL $=94 \mathrm{y}$ Nenguange: $\left.\mathrm{Chi}^{2}=1888,8 ; \mathrm{P}<0,05 ; \mathrm{GL}=90\right)$.

No obstante, el análisis individual por categorías mostró que la cobertura de céspedes, aunque si varía
However, the individual analysis by categories showed that the turf cover, although it varies between reefs $(\mathrm{KW}=23.4 ; \mathrm{P}<0.05)$ does not vary between substrates (Granate: $\mathrm{KW}=1.8 ; \mathrm{P}=>0.05$ and Nenguange: $\mathrm{KW}=0.7$; $\mathrm{P}=>0.05)$. In Nenguange, turfs occupied $84.3 \pm 2.3 \%$ (M. cavernosa $=78.8 \pm 5.3 \%$, P. strigosa $=87.1 \pm 2.7$ and $S$. siderea $=87.1 \pm 2.6 \%$ ), while, in Granate, they represented $61.9 \pm 3.5 \%(M$. cavernosa $=61.7 \pm 5.8 \%$; P. strigosa $=67.1 \pm 5.7 \%$ and $S$. intersepta $=55.4 \pm 6.8 \%$ ) (Figure 4A). 
entre arrecifes $(\mathrm{K}-\mathrm{W}=23,4 ; \mathrm{P}<0,05)$ no varía entre sustratos (Granate: $\mathrm{K}-\mathrm{W}=1,8 ; \mathrm{P}=>0,05$ y Nenguange: $\mathrm{K}-\mathrm{W}=0,7 ; \mathrm{P}=>0,05)$. En Nenguange, los céspedes ocuparon 84,3 $\pm 2,3 \%$ (M. cavernosa $=78,8 \pm 5,3 \%$, P. strigosa $=87,1 \pm 2,7$ y $S$. siderea $=87,1 \pm 2,6 \%$ ), mientras que en Granate representaron $61,9 \pm 3,5 \%$ (M. cavernosa $=61,7 \pm 5,8 \% ;$ P. strigosa $=67,1 \pm 5,7 \% \mathrm{y}$ $S$. intersepta $=55,4 \pm 6,8 \%$ ) (Figura 4A).

Para las algas costrosas también se encontraron diferencias entre arrecifes $(\mathrm{K}-\mathrm{W}=10,4 ; \mathrm{P}<0,05)$. Entre sustratos solo se hallaron diferencias en Granate $(\mathrm{K}-\mathrm{W}=6,8$; $\mathrm{P}=<0,05)$, donde esta cobertura representó $24,2 \pm 4,1 \%$, siendo significativamente mayor sobre esqueletos de S. intersepta $(36,2 \pm 8,2 \%)$, respecto a $M$. cavernosa $(25,0 \pm 6,4 \%)$ y $P$. strigosa $(14,1 \pm 6,3 \%)$. En Nenguange no se encontraron diferencias entre sustratos $(\mathrm{K}-\mathrm{W}=1,7$; $\mathrm{P}=0,05)$, y estas algas representaron solo $6,5 \pm 1,9 \%$ de la cobertura de los núcleos $(M$. cavernosa $=10,6 \pm 4,2 \%$; P. strigosa $=4,7 \pm 2,7 \%$ y $S$. siderea $=3,8 \pm 1,8 \%$ ) (Figura 4A).

Para la categoría esqueleto desnudo, no se encontraron diferencias entre arrecifes $(\mathrm{K}-\mathrm{W}=0,9$; $\mathrm{P}>0,05)$ ni entre sustratos (Granate: $\mathrm{K}-\mathrm{W}=3,7$; $\mathrm{P}=>0,05$ y Nenguange: $\mathrm{K}-\mathrm{W}=0,9 ; \mathrm{P}=>0,05)$. En Granate, esta categoría representó $14,0 \pm 2,7 \%$ de la cobertura de los núcleos $(M$. cavernosa $=13,3 \pm 5,2 \%$; P. strigosa $=18,8 \pm 4,6 \%$ y $S$. intersepta $=8,5 \pm 3,6 \%$ ), y en Nenguange 9,1 $\pm 1,7 \%$ ( $M$. cavernosa $=10,6 \pm 3,8 \%$; P. strigosa $=8,2 \pm 2,1 \%$ y $S$. siderea $=8,5 \pm 2,7 \%$ ) (Figura 4A).

Las pruebas de independencia mostraron que la densidad de filamentos depende del arrecife $\left(\mathrm{Chi}^{2}=296,5\right.$; $\mathrm{P}<0,05 ; \mathrm{GL}=10$ ) y el sustrato coralino (Granate: $\mathrm{Chi}^{2}=36,2 ; \mathrm{P}<0,05 ; \mathrm{GL}=4$ y Nenguange: $\mathrm{Chi}^{2}=82,4$; $\mathrm{P}<0,05 ; \mathrm{GL}=4)$. En Granate, dominaron los tapetes moderadamente tupidos $(45,8 \%)$ y dispersos altos (39,6\%), mientras que los tapetes densos y cortos solo representaron $14,6 \%$. Por el contrario, en Nenguange dominaron los céspedes densos y cortos $(65,2 \%)$, mientras que los tapetes moderadamente tupidos y dispersos altos representaron solo $21,7 \%$ y $13,0 \%$, respectivamente (Figura $4 \mathrm{~B}$ ).

\section{Biomasa algal}

No se encontraron diferencias significativas en la biomasa algal entre arrecifes ( $\mathrm{M}-\mathrm{WU}=1120,0 ; \mathrm{n}_{\text {Granate }}=49$; $\left.\mathrm{n}_{\text {Nenguange }}=46 ; \mathrm{P}>0,05\right)$, pero si entre sustratos (Granate:
Differences between reefs were also found for crusted algae $(\mathrm{K}-\mathrm{W}=10.4 ; \mathrm{P}<0.05)$. Between substrates, differences were only found in Granate $(\mathrm{KW}=6.8$; $\mathrm{P}=<0.05)$, where this coverage represented $24.2 \pm 4.1 \%$, being significantly higher on skeletons of $S$. intersepta $(36.2$ $\pm 8.2 \%)$, compared to $M$. cavernosa $(25.0 \pm 6.4 \%)$ and $P$. strigosa $(14.1 \pm 6.3 \%)$. In Nenguange no differences were found between substrates ( $\mathrm{KW}=1.7 ; \mathrm{P}=>0.05)$, and these algae represented only $6.5 \pm 1.9 \%$ of the nuclei coverage (M. cavernosa $=10.6 \pm 4.2 \%$; . strigos $a=4.7 \pm 2.7 \%$ and S. siderea $=3.8 \pm 1.8 \%$ ) (Figure 4A).

For the bare skeleton category, no differences were found between reefs $(\mathrm{KW}=0.9 ; \mathrm{P}>0.05)$ or between substrates (Granate: $\mathrm{KW}=3.7 ; \mathrm{P}=>0.05$ and Nenguange: $\mathrm{KW}=0.9 ; \mathrm{P}=>0.05)$. In Granate, this category represented $14.0 \pm 2.7 \%$ of the nuclei coverage (M. cavernosa $=13.3$ $\pm 5.2 \%$; P. strigosa $=18.8 \pm 4.6 \%$ and $S$. intersepta $=8.5$ $\pm 3.6 \%$, and in Nenguange $9.1 \pm 1.7 \%$ (M. cavernosa $=$ $10.6 \pm 3.8 \%$; P. strigosa $=8.2 \pm 2.1 \%$ and $S$. siderea $=8.5$ $\pm 2.7 \%$ ) (Figure $4 \mathrm{~A}$ ).

The independence tests showed that the filament density depends on the reef $\left(\mathrm{Chi}^{2}=296.5 ; \mathrm{P}<0.05 ; \mathrm{GL}=10\right)$ and the coral substrate (Granate: $\mathrm{Chi}^{2}=36.2 ; \mathrm{P}<0.05$; $\mathrm{GL}=4$ and Nenguange: $\left.\mathrm{Chi}^{2}=82.4 ; \mathrm{P}<0.05 ; \mathrm{GL}=4\right)$. In Granate, moderately dense rugs (45.8\%) and tall scattered rugs $(39.6 \%)$ dominated, while dense and short rugs only represented $14.6 \%$. In contrast, in Nenguange dense and short turfs dominated $(65.2 \%)$, while moderately dense and sparse tall rugs accounted for only $21.7 \%$ and $13.0 \%$, respectively (Figure 4B).

\section{Algal biomass}

No significant differences were found in algal biomass between reefs $\left(\mathrm{M}-\mathrm{WU}=1120.0 ; \mathrm{n}_{\text {Granate }}=49\right.$; $\left.\mathrm{n}_{\text {Nenguange }}=46 ; \mathrm{P}>0.05\right)$, but there were between substrates (Granate: KW = 10.9; $\mathrm{P}<0.05$ and Nenguange: $\mathrm{KW}=19.5$; $\mathrm{P}<0.05)$. In Granate, the algal biomass was higher on skeletons of $P$. strigosa, and in Nenguange it was significantly lower on skeletons of $S$. siderea (Figure 5).

In Granate, the average algal biomass was $0.012 \pm 0.002 \mathrm{~g} \cdot \mathrm{cm}^{-2}$ with variations between 0.077 and $0.002 \mathrm{~g} \cdot \mathrm{cm}^{-2}\left(M\right.$. cavernosa $=0.007 \pm 0.001 \mathrm{~g} \cdot \mathrm{cm}^{-2}$; P. strigosa $=0.021 \pm 0.005 \mathrm{~g} \cdot \mathrm{cm}^{-2}$ and $S$. intersepta $=$ $0.008 \pm 0.003 \mathrm{~g} \cdot \mathrm{cm}^{-2}$ ), and in Nenguange it was 0.010 $\pm 0.001 \mathrm{~g} \cdot \mathrm{cm}^{-2}$ with variations between 0.036 and $0.002 \mathrm{~g} \cdot \mathrm{cm}^{-2}\left(\right.$ M. cavernosa $=0.012 \pm 0.002 \mathrm{~g} \cdot \mathrm{cm}^{-2}$; 


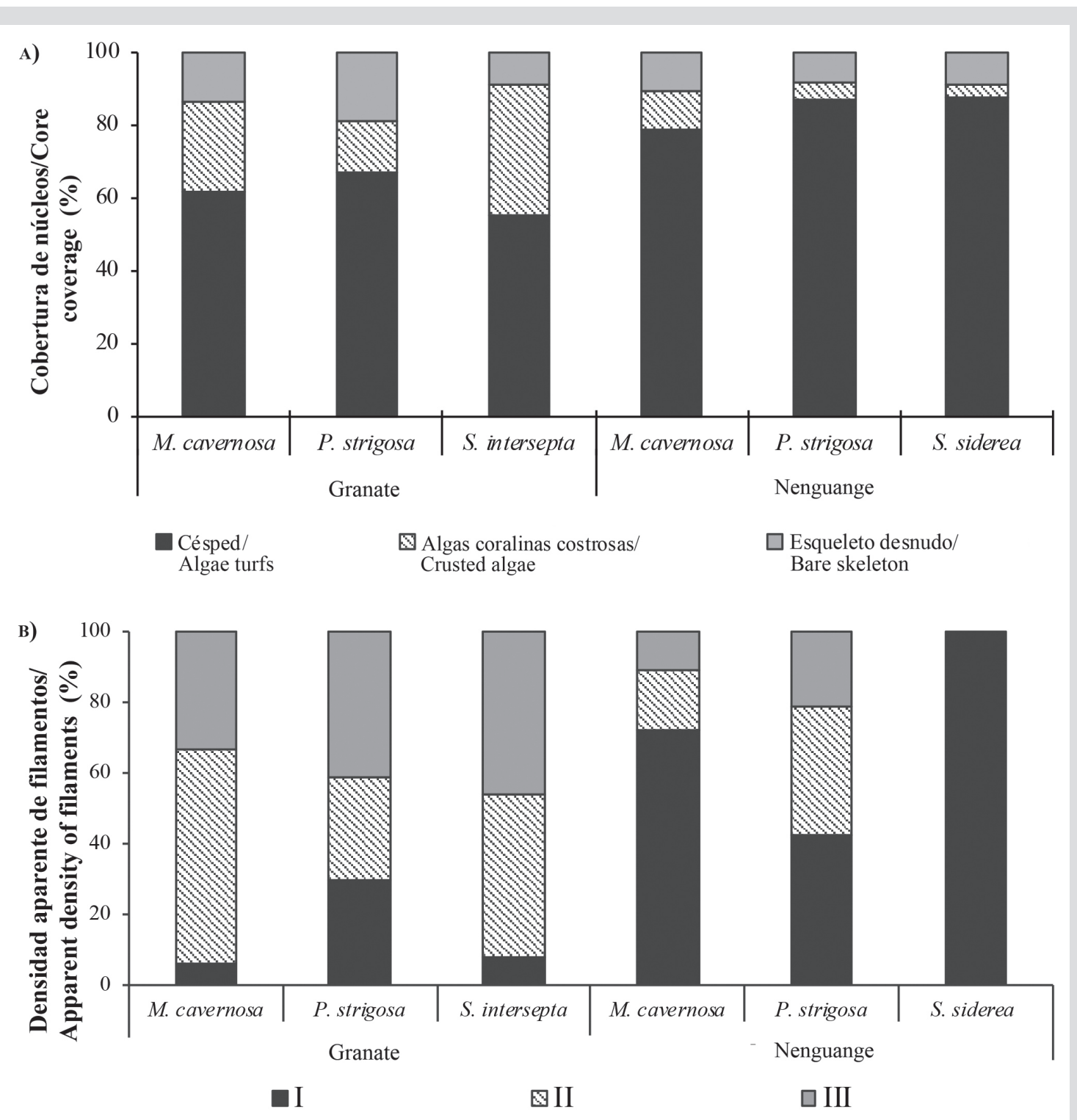

Figura 4. A) Cobertura (\%) de céspedes algales, algas costrosas y esqueleto desnudo y B) densidad de filamentos algales (\%) en núcleos recolectados cerca de interfaces coral-césped, en los arrecifes de Granate y Nenguange (PNN Tayrona). Convenciones para densidad: I - filamentos cortos y densamente agregados $(\sim<2 \mathrm{~mm})$; II - filamentos moderadamente largos y tupidos $(\sim 2-5 \mathrm{~mm})$ y III - filamentos altos y dispersos $(\sim>5 \mathrm{~mm})$. El \% de cobertura corresponde al valor combinado para todos los núcleos por sustrato (especie coralina). El \% de densidad es resultado del número de núcleos designados en cada categoría en relación con el total de núcleos por sustrato.
Figure 4. A) Cover (\%) of algae turfs, crusted algae, and bare skeleton, and B) density of algae filaments (\%) in cores collected near coralturf interfaces, in the Granate and Nenguange reefs (Tayrona PNN). Conventions for density: I - short and densely aggregated filaments $(\sim<2 \mathrm{~mm})$; II - moderately long and bushy filaments $(\sim 2-5 \mathrm{~mm})$, and III - tall and sparse filaments $(\sim>5 \mathrm{~mm})$. The \% coverage corresponds to the combined value for all nuclei per substrate (coral species). The $\%$ density is the result of the number of designated nuclei in each category concerning the total of nuclei per substrate.
$\mathrm{K}-\mathrm{W}=10,9 ; \mathrm{P}<0,05$ y Nenguange: $\mathrm{K}-\mathrm{W}=19,5 ; \mathrm{P}<0,05)$. En Granate la biomasa algal fue mayor sobre esqueletos de $P$. strigosa, y en Nenguange fue significativamente menor sobre esqueletos de $S$. siderea (Figura 5).

En Granate, la biomasa algal promedio fue de 0,012 $\pm 0,002 \mathrm{~g} \cdot \mathrm{cm}^{-2}$ con variaciones entre $0,077 \mathrm{y} 0,002 \mathrm{~g} \cdot \mathrm{cm}^{-2}$ (M. cavernosa $=0,007 \pm 0,001 \mathrm{~g} \cdot \mathrm{cm}^{-2} ;$. strigosa $=0,021$
P. strigosa $=0.013 \pm 0.002 \mathrm{~g} \cdot \mathrm{cm}^{-2}$ and $S$. siderea $=0.004 \pm$ $\left.0.001 \mathrm{~g} \cdot \mathrm{cm}^{-2}\right)$ (Figure 5).

Sediment accumulated at the edges of coral-turf interaction

Statistical differences were found in the total amount of accumulated sediments between reefs 


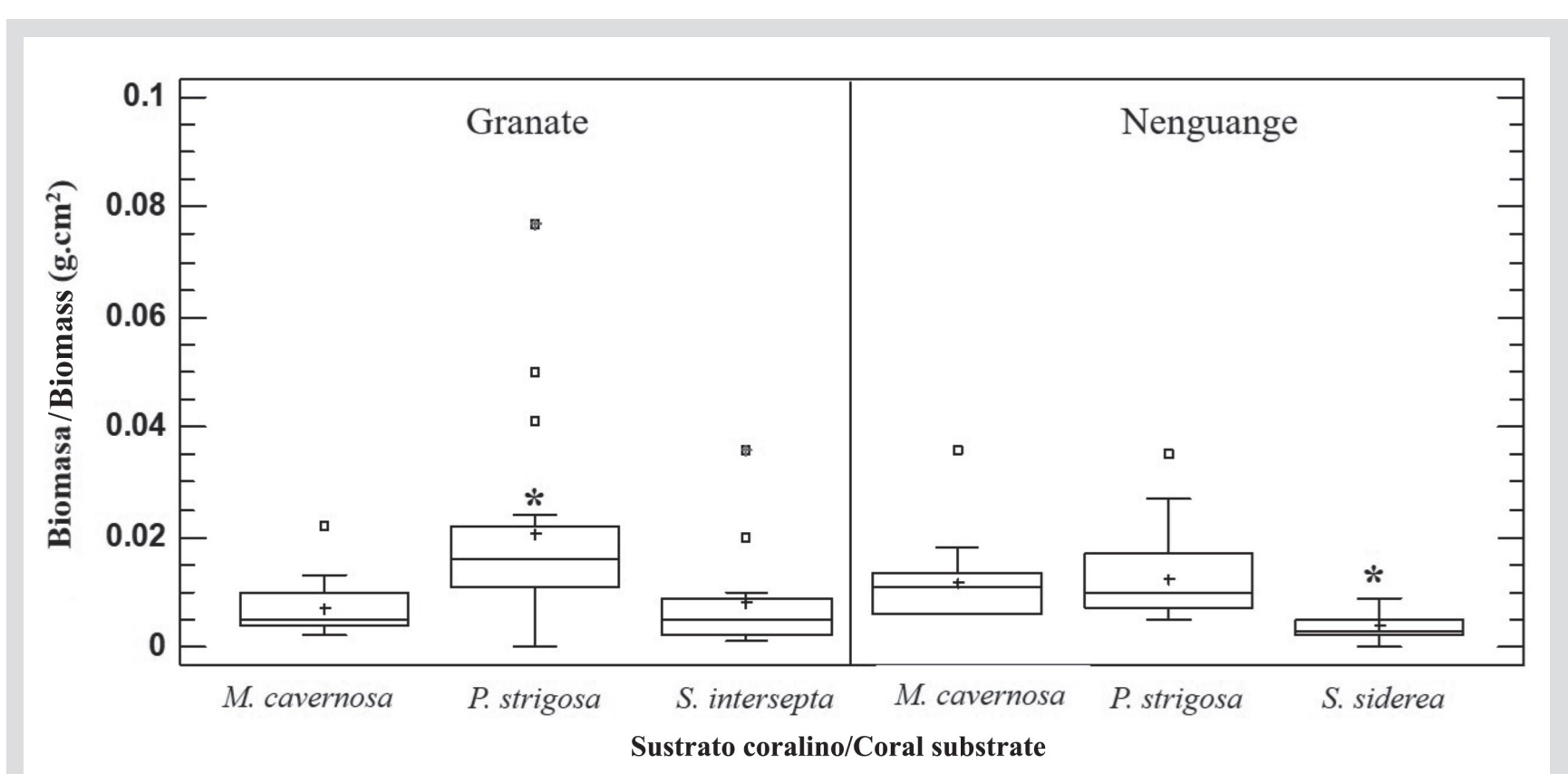

Figura 5. Biomasa de céspedes algales $\left(\mathrm{g} \cdot \mathrm{cm}^{-2}\right)$ que crece sobre esqueletos coralinos en los arrecifes de Granate y Nenguange (PNN Tayrona). Las barras horizontales indican la mediana, las cajas el primer y tercer cuartil, los bigotes el rango de los datos, la cruz $(+)$ el promedio, los cuadrados los valores extremos, y los asteriscos $\left(^{*}\right)$ indican los sustratos con promedios significativamente diferentes.
Figure 5. Algal turf biomass $\left(\mathrm{g} \cdot \mathrm{cm}^{-2}\right)$ that grows on coral skeletons in the Granate and Nenguange reefs (PNN Tayrona). The horizontal bars indicate the median, the boxes the first and third quartiles, the whiskers the range of the data, the cross $(+)$ the average, the squares the extreme values, and the asterisks $(*)$ indicate the substrates with significantly different averages. $\pm 0,005 \mathrm{~g} \cdot \mathrm{cm}^{-2}$, y $S$. intersepta $\left.=0,008 \pm 0,003 \mathrm{~g} \cdot \mathrm{cm}^{-2}\right), \mathrm{y}$ en Nenguange fue de $0,010 \pm 0,001 \mathrm{~g} \cdot \mathrm{cm}^{-2}$ con variaciones entre 0,036 y $0,002 \mathrm{~g} \cdot \mathrm{cm}^{-2}$ (M. cavernosa $=0,012 \pm 0,002 \mathrm{~g} \cdot \mathrm{cm}^{-2}$; P. strigosa $=0,013 \pm 0,002 \mathrm{~g} \cdot \mathrm{cm}^{-2}, \mathrm{y} S$. siderea $=0,004 \pm$ $0,001 \mathrm{~g} \cdot \mathrm{cm}^{-2}$ ) (Figura 5).

\section{Sedimentos acumulados en bordes}

de interacción coral-césped

Se encontraron diferencias estadísticas en la cantidad total de sedimentos acumulados entre arrecifes ( $\left.\mathrm{M}-\mathrm{WU}=777,5 ; \mathrm{n}_{\text {Granate }}=60 ; \mathrm{n}_{\text {Nenguange }}=58 ; \mathrm{P}<0,05\right)$ y sustratos (Granate: $\mathrm{K}-\mathrm{W}=20,9 ; \mathrm{P}<0,05$ y Nenguange: $\mathrm{K}-\mathrm{W}=6,3$; $\mathrm{P}<0,05)$, siendo en promedio mayor en Granate $(0,075 \pm$ $0,003 \mathrm{~g} \cdot \mathrm{cm}^{-2}$, con variaciones entre 0,045 y $\left.0,173 \mathrm{~g} \cdot \mathrm{cm}^{-2}\right)$ que en Nenguange $\left(0,056 \pm 0,003 \mathrm{~g} \cdot \mathrm{cm}^{-2}\right.$, con variaciones entre 0,020 y $\left.0,147 \mathrm{~g} \cdot \mathrm{cm}^{-2}\right)$, y significativamente más abundantes sobre esqueletos de $P$. strigosa (Granate $=0,094$ $\pm 0,007 \mathrm{~g} \cdot \mathrm{cm}^{2}$; Nenguange $\left.=0,065 \pm 0,006 \mathrm{~g} \cdot \mathrm{cm}^{2}\right)$ que de $M$. cavernosa (Granate $=0,067 \pm 0,003$ g.cm $;$ Nenguange $=$ $0,053 \pm 0,003$ g.cm ${ }^{2}$ ), S intersepta (Granate $=0,062 \pm 0,003$ g. $\left.\mathrm{cm}^{2}\right)$ y $S$. siderea (Nenguange $=0,049 \pm 0,002$ g. $\mathrm{cm}^{2}$ ) (Figura 6A).

Según el tamaño del grano, la prueba de independencia determinó que la proporción entre fracciones
$\left(\mathrm{M}-\mathrm{WU}=777.5 ; \mathrm{n}_{\text {Granate }}=60 ; \mathrm{n}_{\text {Nenguange }}=58 ; \mathrm{P}<0.05\right)$ and substrates (Granate: $\mathrm{KW}=20.9 ; \mathrm{P}<0.05$ and Nenguange: $\mathrm{KW}=6.3 ; \mathrm{P}<0.05)$, being on average higher in Granate $\left(0.075 \pm 0.003 \mathrm{~g} \cdot \mathrm{cm}^{-2}\right.$, with variations between 0.045 and $\left.0.173 \mathrm{~g} \cdot \mathrm{cm}^{-2}\right)$ than in Nenguange $\left(0.056 \pm 0.003 \mathrm{~g} \cdot \mathrm{cm}^{-2}\right.$, with variations between 0.020 and $\left.0.147 \mathrm{~g} \cdot \mathrm{cm}^{-2}\right)$, and significantly more abundant on P. strigosa skeletons (Granate $=0.094$ $\pm 0.007 \mathrm{~g} . \mathrm{cm}^{2}$; Nenguange $\left.=0.065 \pm 0.006 \mathrm{~g} . \mathrm{cm}^{2}\right)$ than on skeletons of $M$. cavernosa (Granate $=0.067 \pm 0.003 \mathrm{~g} . \mathrm{cm}^{2}$; Nenguange $\left.=0.053 \pm 0.003 \mathrm{~g} . \mathrm{cm}^{2}\right)$, S. intersepta $($ Granate $=$ $\left.0.062 \pm 0.003 \mathrm{~g} . \mathrm{cm}^{2}\right)$ and S. siderea (Nenguange $=0.049 \pm$ 0.002 g.cm ${ }^{2}$ ) (Figure 6A).

According to the grain size, the independence test determined that the proportion between fractions also depends on the reef $\left(\mathrm{Chi}^{2}=1172.2 ; \mathrm{P}<0.05 ; \mathrm{GL}=117\right)$ and the substrate (Granate: $\mathrm{Chi}^{2}=506.1 ; \mathrm{P}<0.05$; GL $=$ 59 and Nenguange: $\left.\mathrm{Chi}^{2}=633.5 ; \mathrm{P}<0.05 ; \mathrm{GL}=57\right)$. On average, silt-clays are more abundant (Granate $=86.1 \pm$ $1.3 \%$; Nenguange $=83.0 \pm 1.6 \%$ ) than sands (Granate $=$ $13.9 \pm 1.3 \%$; Nenguange $=17.0 \pm 1.6 \%$, and on skeletons of S. intersepta (Granate) and S. siderea (Nenguange) a lesser amount of coarse material accumulates compared to M. cavernosa and P. strigosa (Figure 6B). 


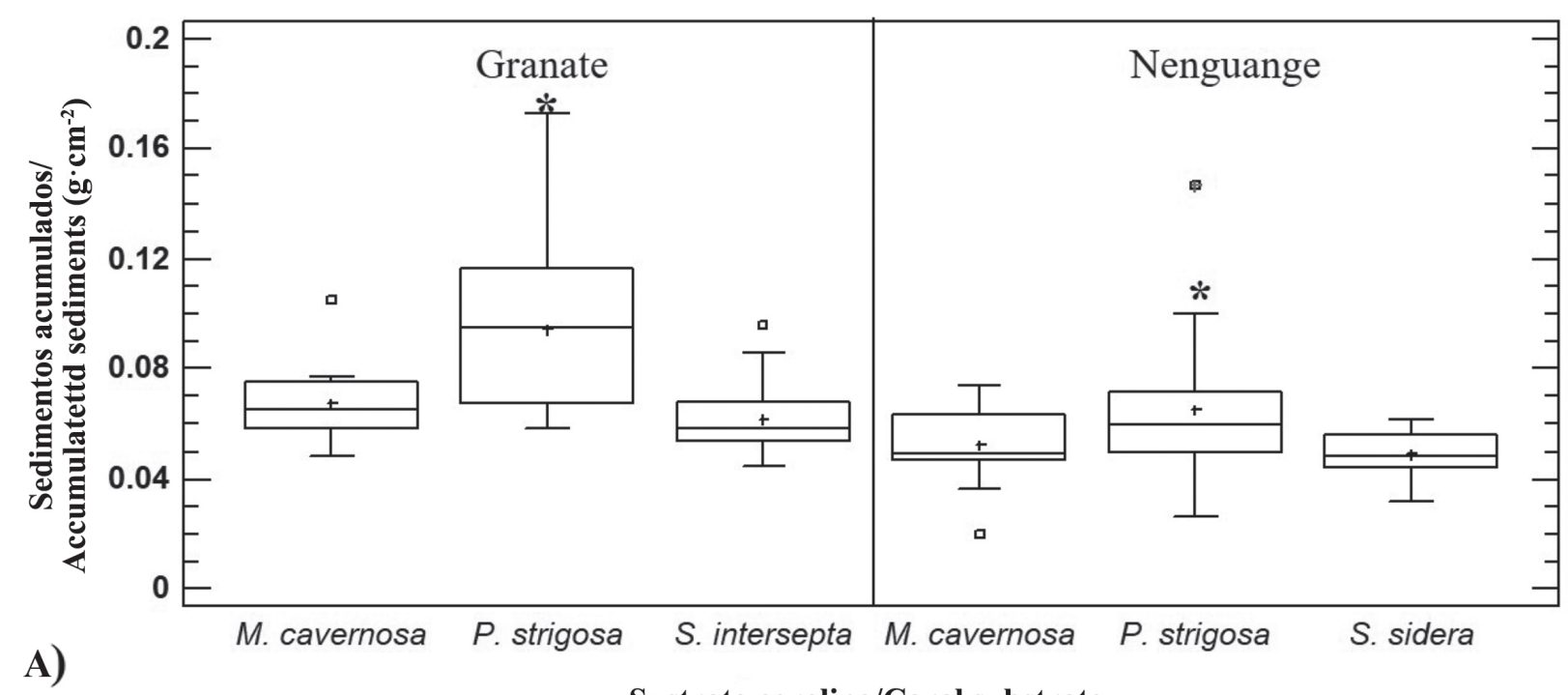

Sustrato coralino/Coral substrate

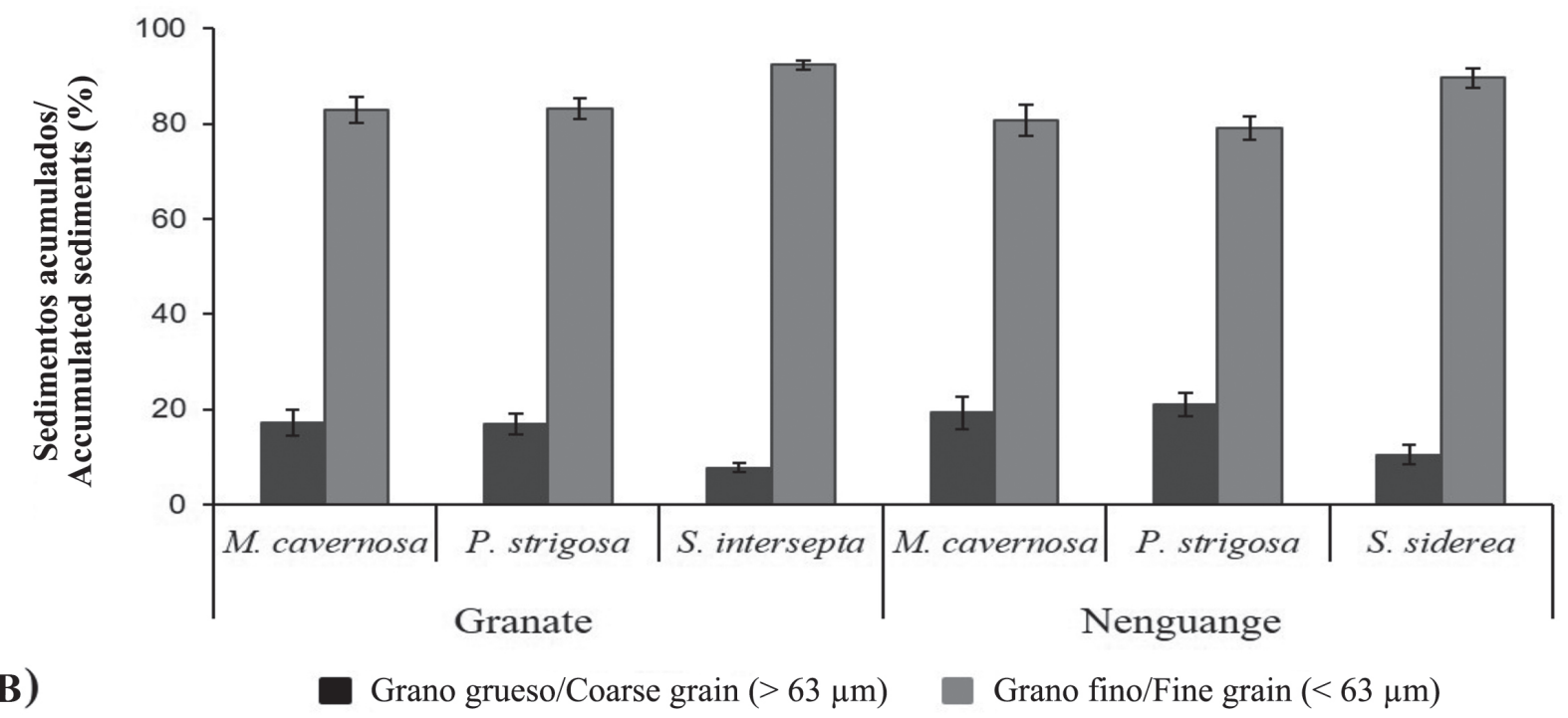

Figura 6. Sedimentos $\left(\mathrm{g} \cdot \mathrm{cm}^{-2}\right)$ acumulados en bordes de interacción coral-césped, en los arrecifes de Granate y Nenguange PNN Tayrona: A) Sedimentos totales, las barras horizontales indican la mediana, las cajas el primer y tercer cuartil, los bigotes el rango de datos, la cruz (+) el promedio, los cuadrados los valores extremos y los asteriscos (*) los sustratos con promedio significativamente diferente. B) Según el tamaño de grano $(\%)$ como fracción gruesa/arenas $(>63 \mu \mathrm{m})$ y fracción fina/ limos-arcillas $(<63 \mu \mathrm{m})$.
Figure 6. Sediments $\left(\mathrm{g} \cdot \mathrm{cm}^{-2}\right)$ accumulated at the edges of the coralturf interaction, in the reefs of Granate and Nenguange Tayrona NNP: A) Total sediments, the horizontal bars indicate the median, the boxes the first and third quartiles, the whiskers the data range, the cross $(+)$ the average, the squares the extreme values and the asterisks $(*)$ the substrates with significantly different average. B) According to the grain size $(\%)$ as coarse fraction/sand $(>63 \mu \mathrm{m})$ and fine fraction/silt-clays $(<63 \mu \mathrm{m})$. también depende del arrecife $\left(\mathrm{Chi}^{2}=1172,2 ; \mathrm{P}<0,05\right.$; GL $=117$ ) y del sustrato (Granate: $\mathrm{Chi}^{2}=506,1 ; \mathrm{P}<0,05$; GL $=59$ y Nenguange: $\left.\mathrm{Chi}^{2}=633,5 ; \mathrm{P}<0,05 ; \mathrm{GL}=57\right) . \mathrm{En}$ promedio, los limos-arcillas son más abundantes (Granate $=$ $86,1 \pm 1,3 \%$; Nenguange $=83,0 \pm 1,6 \%$ ) que las arenas $($ Granate $=13,9 \pm 1,3 \%$; Nenguange $=17,0 \pm 1,6 \%), \mathrm{y}$ sobre esqueletos de $S$. intersepta (Granate) y $S$. siderea

\section{Association between accumulated} sediments with the structure of turfs

In general, it was found that there is a positive correlation between the total amount of sediments accumulated at the edges of coral-turf interaction with the algal biomass $(\mathrm{r}=0.23 ; \mathrm{P}<0.05 ; \mathrm{n}=91)$, particularly when the fraction of the sediment is fine $(\mathrm{r}=0.32 ; \mathrm{P}<0.05 ; \mathrm{n}=91)$. 
(Nenguange) se acumula una menor cantidad de material grueso respecto a M. cavernosa y P. strigosa (Figura 6B).

Asociación entre los sedimentos acumulados con la estructura de los céspedes

En general, se encontró que existe correlación positiva entre la cantidad total de sedimentos acumulados en bordes de interacción coral-césped con la biomasa algal $(\mathrm{r}=0,23 ; \mathrm{P}<0,05 ; \mathrm{n}=91)$, particularmente cuando la fracción del sedimento es fina $(\mathrm{r}=0,32 ; \mathrm{P}<0,05 ; \mathrm{n}=91)$.

Según el arrecife, en Granate se encontró correlación positiva entre la biomasa con la cantidad total de sedimentos $(\mathrm{r}=0,34 ; \mathrm{P}<0,05 ; \mathrm{n}=47)$ y la cantidad de limos-arcillas $(r=0,31 ; P<0,05 ; n=47)$, pero en Nenguange las variables que se correlacionaron positivamente fueron la altura del dosel con los limos-arcillas acumuladas $(\mathrm{r}=0,31 ; \mathrm{P}<0,05$; $\mathrm{n}=44$ ).

Según la cobertura por género, en los dos arrecifes se encontró que la cantidad de sedimentos totales tiene correlación positiva con la cobertura de algas calcáreas articuladas y corticadas $\left(\mathrm{r}_{\text {Amphiroa }}=0,24 ; \mathrm{r}_{\text {Gelidiella }}=0,24 ; \mathrm{P}<0,05\right.$; $\mathrm{n}=91$ ), pero tiene correlación negativa con la cobertura de algas filamentosas $\left(\mathrm{r}_{\text {Ceramium }}=-0,23 ; \mathrm{r}_{\text {Polysiphonia }}=-0,26 ; \mathrm{P}<0,05\right.$; $\mathrm{n}=91)$ y cianobacterias $(\mathrm{r}=-0,31 ; \mathrm{P}<0,05 ; \mathrm{n}=91)$.

Según el tamaño del grano, se encontró que una mayor acumulación de sedimentos finos tiene correlación positiva con una mayor cobertura de Ceramium $(r=0,24$; $\mathrm{P}<0,05 ; \mathrm{n}=91)$, mientras que una mayor acumulación de sedimentos gruesos tienen correlación positiva con una mayor cobertura de algas calcáreas articuladas, corticadas $\mathrm{y}$ frondosas $\left(\mathrm{r}_{\text {Amphiroa }}=0,25 ; \mathrm{r}_{\text {Gelidiella }}=0,31 ; \mathrm{r}_{\text {Dictyota }}=0,23\right.$; $\mathrm{P}<0,05 ; \mathrm{n}=91)$, pero tiene correlación negativa con la cobertura de algunos géneros filamentosos $\left(\mathrm{r}_{\text {Ceramium }}=-0,39\right.$; $\mathrm{r}_{\text {Herposiphonia }}=-0,37 ; \quad \mathrm{r}_{\text {Chondria }}=-0,42 ; \quad \mathrm{r}_{\text {Polysiphonia }}=-0,37$; $\left.\mathrm{r}_{\text {Cladophora }}=-0,22 ; \mathrm{P}<0,05 ; \mathrm{n}=91\right)$ y cianobacterias $(\mathrm{r}=-0,35$; $\mathrm{P}<0,05 ; \mathrm{n}=91$ ).

\section{DISCUSIÓN}

Aunque a simple vista los céspedes algales tienen apariencia homogénea, existen evidencias que estos ensamblajes son altamente variables a escala espacial (Harris et al., 2015), según la ubicación, profundidad y perturbaciones que afectan al arrecife (Bonaldo y Bellwood, 2001); variables que en conjunto son determinantes para los procesos de sucesión en estas comunidades (DíazPulido y McCook, 2002; Fricke et al., 2011). Aunque Harris
According to the reef, in Granate a positive correlation was found between the biomass with the total amount of sediments $(\mathrm{r}=0.34 ; \mathrm{P}<0.05 ; \mathrm{n}=47)$ and the amount of silt-clays $(r=0.31 ; P<0.05 ; n=47)$, but in Nenguange, the variables that were positively correlated were the height of the canopy with the accumulated siltclays $(\mathrm{r}=0.31 ; \mathrm{P}<0.05 ; \mathrm{n}=44)$.

According to the cover by genus, in the two reefs it was found that the amount of total sediments has a positive correlation with the cover of articulated and corticated calcareous algae $\left(\mathrm{r}_{\text {Amphiroa }}=0.24 ; \mathrm{r}_{\text {Gelidiella }}=0.24 ; \mathrm{P}<0.05\right.$; $\mathrm{n}=91$ ), but it has a negative correlation with the cover of filamentous algae $\left(\mathrm{r}_{\text {Ceramium }}=-0.23 ; \mathrm{r}_{\text {Polysiphonia }}=-0.26 ; \mathrm{P}<0.05\right.$; $\mathrm{n}=91)$ and cyanobacteria $(\mathrm{r}=-0.31 ; \mathrm{P}<0.05 ; \mathrm{n}=91)$.

According to the grain size, it was found that a greater accumulation of fine sediments has a positive correlation with a greater coverage of Ceramium $(r=0.24$; $\mathrm{P}<0.05 ; \mathrm{n}=91$ ), while a greater accumulation of coarse sediments have a positive correlation with a greater coverage of articulated, corticated and leafy calcareous algae $\left(\mathrm{r}_{\text {Amphiroa }}=0.25 ; \mathrm{r}_{\text {Gelidiella }}=0.31 ; \mathrm{r}_{\text {Dictyota }}=0.23 ; \mathrm{P}<0.05\right.$; $\mathrm{n}=91$ ), but it has negative correlation with the coverage of some filamentous genera $\left(\mathrm{r}_{\text {Ceramium }}=-0.39 ; \mathrm{r}_{\text {Herposiphonia }}=-0.37\right.$; $\mathrm{r}_{\text {Chondria }}=-0.42 ; \mathrm{r}_{\text {Polysiphonia }}=-0.37 ; \mathrm{r}_{\text {Cladophora }}=-0.22 ; \mathrm{P}<0.05$; $\mathrm{n}=91)$ and cyanobacteria $(\mathrm{r}=-0.35 ; \mathrm{P}<0.05 ; \mathrm{n}=91)$.

\section{DISCUSSION}

Although algae turfs appear homogeneous at first glance, there is evidence that these assemblages are highly variable on a spatial scale (Harris et al., 2015), depending on the location, depth, and disturbances that affect the reef (Bonaldo and Bellwood, 2001); variables that together are determinants for the succession processes in these communities (Díaz-Pulido and McCook, 2002; Fricke et al., 2011). Although Harris et al. (2015) suggest that this structural variability is greater on a small scale $(\mathrm{cm})$ than between separate reefs (from $\mathrm{m}$ to $\mathrm{km}$ ). This research showed that between stations (separated by $\mathrm{km}$ ) and type of colonized substrate (colonies separated by $\mathrm{m}$ ), There are important structural differences and that this variability, expressed in terms of structural complexity, gives algal turfs certain competitive advantages in interactions with living coral tissue, such as, for example, a greater capacity to retain and accumulate sediments in their fronds.

Among reefs, the most important structural variables were the composition and cover of the algal 
et al. (2015) sugieren que esta variabilidad estructural es mayor a pequeña escala $(\mathrm{cm})$ que entre arrecifes separados (desde $\mathrm{m}$ a $\mathrm{km}$ ). Esta investigación demostró que entre estaciones (separadas por $\mathrm{km}$ ) y tipo de sustrato colonizado (colonias separadas por $\mathrm{m}$ ), existen diferencias estructurales importantes, y que esta variabilidad expresada en términos de complejidad estructural les confiere a los céspedes algales ciertas ventajas competitivas en interacciones con tejido vivo coralino como, por ejemplo, una mayor capacidad para retener y acumular sedimentos en sus frondas.

Entre arrecifes, las variables estructurales más importantes fueron la composición y cobertura de los géneros algales, la cobertura relativa por categorías (céspedes, algas costrosas y esqueleto desnudo), la densidad de filamentos, y la cantidad total y por fracción de sedimentos. Mientras que, entre sustratos colonizados, varió la cobertura por categorías, particularmente de algas costrosas, la densidad de filamentos, la biomasa, y la cantidad total y por fracción de sedimentos.

En general, los céspedes que colonizan esqueletos de corales masivos en Granate forman tapetes discontinuos de algas cespitosas que comparten el sustrato con parches de algas costrosas. Estos céspedes están conformados por ramas altas erectas y postradas de algas calcáreas articuladas, pequeñas corticadas y juveniles de frondosas, especialmente de Dictyota. Este género determina el carácter transicional de estos ensamblajes, ya que durante los meses de afloramiento costero se desarrollan y forman tapetes con doseles altos y densos, que invaden los bordes de interacción coral-césped, hasta que las condiciones ambientales favorecen nuevamente el dominio de los céspedes. En contraste, los céspedes algales en Nenguange al parecer son perennes o permanentes en el tiempo, se desarrollan como tapetes cortos, muy tupidos y densos, con escasa presencia de algas costrosas, y están conformados por algas filamentosas y pequeñas corticadas.

Inicialmente, estas diferencias pueden atribuirse a las características topográficas de cada arrecife, a su cercanía al área de influencia de la zona urbana/portuaria de Santa Marta y a la profundidad de muestreo. Según Fricke et al. (2011), a medida que aumenta la profundidad los ensamblajes de céspedes tienden a ser estructuralmente más complejos. Sin embargo, Harris et al. (2015) argumentan que la herbivoría es el proceso que ejerce mayor control sobre la abundancia y distribución de estas comunidades algales.

Al respecto, Burkepile y Hay (2010) mencionan que los céspedes compuestos por taxa simples, generalmente las formas filamentosas que son de fácil digestión, indican genera, the relative cover by categories (turfs, crusted algae, and bare skeleton), the density of filaments, and the total amount and by a fraction of sediments. While, among colonized substrates, the coverage by categories, particularly of crusted algae, the density of filaments, biomass, and the total amount and by a fraction of sediments varied.

In general, the turfs that colonize massive coral skeletons in Granate form discontinuous mats of tussock algae that share the substrate with patches of crusty algae. These turfs are made up of tall, erect, and prostrate branches of articulated calcareous algae, small corticates, and juvenile hardwoods, especially Dictyota. This genus determines the transitional character of these assemblages, since, during the months of the coastal outcrop, mats with high and dense canopies develop and form, which invade the edges of coralturf interaction, until environmental conditions again favor the dominance of the turfs. In contrast, the algal turfs in Nenguange appear to be perennial or permanent over time, they develop as short, very dense, and dense mats, with little presence of crusted algae, and are made up of filamentous and small corticates algae.

Initially, these differences can be attributed to the topographic characteristics of each reef, its proximity to the area of influence of the urban/port area of Santa Marta and the depth of sampling. According to Fricke et al. (2011), as the depth increases the assemblages of turfs tend to be structurally more complex. However, Harris et al. (2015) argue that herbivory is the process that exercises the greatest control over the abundance and distribution of these algal communities.

In this regard, Burkepile and Hay (2010) mention that turfs made up of simple taxa, generally filamentous forms that are easily digested, indicate strong grazing pressure, a process that keeps turfs in early stages of succession, a hypothesis that would explain why in Nenguange the turfs are shorter, dense and dominated by small filamentous algae. For their part, Díaz-Pulido and McCook (2002) and Fricke et al. (2011) argue that in reefs with reduced herbivory, turfs increase in coverage and biomass, and tend to progress towards more complex morphological assemblages, including macroalgal juvenile stages. This assumption would support the results found in Granate, where mats dominated discontinuous of tall turfs between crusted algae, formed by articulated calcareous algae, small corticates, and juvenile hardwoods. These hypotheses coincide with the results obtained by DíazRuíz (2010), who affirms that in the reefs of the Tayrona 
una fuerte presión de pastoreo, proceso que mantiene a los céspedes en etapas tempranas de sucesión, hipótesis que explicaría por qué en Nenguange los céspedes son más cortos, densos y dominados por pequeñas algas filamentosas. Por su parte, Díaz-Pulido y McCook (2002) y Fricke et al. (2011) argumentan que en arrecifes con herbivoría reducida, los céspedes aumentan en cobertura y biomasa y tienden a progresar hacia ensamblajes morfológicamente más complejos, llegando a incluir etapas juveniles de macroalgas. Este supuesto respaldaría los resultados encontrados en Granate, donde dominaron los tapetes discontinuos de céspedes altos entre algas costrosas, formados por algas calcáreas articuladas, pequeñas corticadas y juveniles de frondosas. Estas hipótesis coinciden con los resultados obtenidos por Díaz-Ruíz (2010), quien afirma que en los arrecifes del PNN Tayrona, la herbivoría es un factor clave que regula la cobertura, composición y sucesión de las comunidades algales, y que particularmente en Granate una mayor abundancia de céspedes obedece a una menor presión de pastoreo.

Si bien este estudio se limitó a evaluar la estructura de los céspedes que interactúan con tejido vivo coralino, es importante mencionar que en todos los muestreos se realizaron anotaciones sobre la presencia de territorios de peces damisela del género Stegastes en las 120 colonias evaluadas, encontrando que estos territorios son más frecuentes en Nenguange (59 \%) que en Granate (16\%), y que estos peces prefieren cultivar sus jardines sobre colonias de S. siderea y S. intersepta (Gómez-Cubillos, 2018).

Este hallazgo sugiere que la presencia de territorios de damiselas es un factor clave que modula la complejidad estructural de los céspedes. Al respecto, Jones et al. (2006) y Harris (2015) indican que estos peces seleccionan para sus jardines los taxa filamentosos de fácil digestión sobre las algas calcificadas y juveniles de macroalgas, y que generalmente estos céspedes se mantienen recortados y en etapas tempranas o intermedias de sucesión (Fong y Paul, 2011). Además, la presencia en los dos arrecifes de esqueleto desnudo o roca caliza visible en los núcleos analizados, se pueden interpretar como mordeduras recientes de herbívoros, lo que según Wanders (1976) refleja una presión selectiva de pastoreo hacia ciertos taxa, tal vez dirigido hacia las formas filamentosas que crecen debajo de frondas altas, complejas y menos apetecibles.

Para el PNN Tayrona, Acosta et al. (2018) reportan un descenso anual progresivo en la biomasa de peces $\left(\mathrm{g} / \mathrm{m}^{2}\right)$, particularmente en los arrecifes de Granate y Nenguange. Por
NNP, herbivory is a key factor that regulates the coverage, composition, and succession of the algal communities, and that particularly in Granate a greater abundance of turfs is due to lower grazing pressure.

Although this study was limited to evaluating the structure of the turfs that interact with living coral tissue, it is important to mention that, in all the samplings, annotations were made on the presence of damselfish territories of the genus Stegastes in the 120 evaluated colonies, finding that these territories are more frequent in Nenguange (59\%) than in Granate $(16 \%)$ and that these fish prefer to cultivate their gardens on colonies of $S$. siderea and $S$. intersepta (Gómez-Cubillos, 2018).

This finding suggests that the presence of damsel territories is a key factor that modulates the structural complexity of turfs. In this regard, Jones et al. (2006) and Harris (2015) indicate that these fish select easily digestible filamentous taxa for their gardens on calcified algae and juvenile macroalgae, and that generally these turfs are kept trimmed and in early or intermediate stages of succession (Fong and Paul, 2011). Furthermore, the presence in the two reefs of a bare skeleton or limestone rock visible in the nuclei analyzed, can be interpreted as recent herbivore bites, which according to Wanders (1976) reflects a selective grazing pressure towards certain taxa, perhaps directed towards the filamentous forms that grow under tall, complex and less palatable fronds.

For the Tayrona NNP, Acosta et al. (2018) report a progressive annual decline in fish biomass $\left(\mathrm{g} / \mathrm{m}^{2}\right)$, particularly in the Granate and Nenguange reefs. Therefore, it is expected that the potential effect of these changes in the structure of fish communities, especially in the abundance of herbivores, can promote faster successions in turfs, making them less palatable and resistant to grazing, denser and morphologically more complex, and gives them a greater capacity to accumulate and retain sediments, probably with higher microbial loads (Morrison, 1988; Harris, 2015), which in sum would make these turfs more damaging in interactions with living coral tissue.

On grazing dynamics, Arthur et al. (2005), argue that turfs exposed to low herbivory may eventually be replaced by macroalgae. However, this research confirms that in Granate the genus Dictyota in its juvenile stage is an important component in the assemblages of turf, but once the water temperature decreases during the coastal outcrop (Bula-Meyer, 1990), these algae develop and form 
lo tanto, se espera que el efecto potencial de estos cambios en la estructura de las comunidades de peces, especialmente en la abundancia de herbívoros, puede promover sucesiones más rápidas en los céspedes, haciéndolos menos apetecibles y resistentes al pastoreo, más densos y morfológicamente más complejos, y les confiera una mayor capacidad para acumular y retener sedimentos, probablemente con mayores cargas microbianas (Morrison, 1988; Harris, 2015), lo que en suma haría que estos céspedes sean más lesivos en interacciones con tejido vivo coralino.

Sobre la dinámica de pastoreo, Arthur et al. (2005) argumentan que los céspedes expuestos a baja herbivoría pueden ser eventualmente reemplazados por macroalgas. No obstante, con esta investigación se confirma que en Granate el género Dictyota en su etapa juvenil es un componente importante en los ensamblajes de céspedes, pero una vez que disminuye la temperatura del agua durante el afloramiento costero (Bula-Meyer, 1990), estas algas se desarrollan y forman tapetes densos. Por lo tanto, el carácter transicional de estos ensamblajes no se debe asumir como indicador de baja presión por pastoreo, sino como una respuesta estacional de las algas frente a los cambios oceanográficos durante estos meses. Por el contrario, en Nenguange, la condición permanente de los céspedes en el tiempo, la ausencia de macroalgas durante todo el periodo de investigación y la baja cobertura de algas costrosas sobre los esqueletos coralinos sugiere que en este arrecife existen ciertas condiciones ambientales y/o biológicas, aún desconocidas, que están limitando el reclutamiento y asentamiento de macroalgas y algas costrosas, y que probablemente los céspedes o ciertos taxa que lo conforman actúan como inhibidores para el desarrollo de algas de dosel y con crecimiento costroso, fenómeno ya descrito por Kennelly (1987) y Airoldi (2003) en ambientes subtropicales.

Otra variable importante en la diferenciación de los céspedes es su capacidad de crecimiento vegetativo (Harris et al., 2015). En este estudio, solo en $6 \%$ de las muestras analizadas se observaron estructuras reproductivas en algas de los géneros Griffithsia, Chondria, Sphacelaria y Dictyota. Esto indica que, en los dos arrecifes, la propagación vegetativa fue el mecanismo de crecimiento más frecuente de los céspedes durante el periodo evaluado, sin desconocer que puede existir estacionalidad reproductiva mediada por el afloramiento costero. Según Sousa (1979) y Airoldi et al. (1995), esta forma de propagación es una importante ventaja competitiva, porque los céspedes pueden defender el territorio ganado, al impedir el desarrollo de otras algas y dense mats. Therefore, the transitional character of these assemblages should not be assumed as an indicator of low pressure due to grazing, but rather as a seasonal response of the algae to oceanographic changes during these months. On the contrary, in Nenguange, the permanent condition of the turfs over time, the absence of macroalgae during the entire research period, and the low cover of crusted algae on the coral skeletons suggest that certain environmental conditions exist on this reef and/or biological, still unknown, that are limiting the recruitment and settlement of macroalgae and crusted algae, and that probably the turfs or certain taxa that comprise it, act as inhibitors for the development of canopy algae and with crusty growth, a phenomenon already described by Kennelly (1987) and Airoldi (2003) in subtropical environments.

Another important variable in the differentiation of turfs is their capacity for vegetative growth (Harris et al., 2015). In this study, only $6 \%$ of the samples analyzed had reproductive structures observed in algae of the genera Griffithsia, Chondria, Sphacelaria, and Dictyota. This indicates that, in the two reefs, vegetative propagation was the most frequent growth mechanism of the turfs during the evaluated period, without ignoring that there may be reproductive seasonality mediated by the coastal outcrop. According to Sousa (1979) and Airoldi et al. (1995), this form of propagation is an important competitive advantage, because turfs can defend the territory gained, by preventing the development of other algae and organisms that colonize with spores and planula, allowing them to capture a greater amount of sediment, which in turn, would serve as a substrate to anchor and advance laterally, covering the adjacent polyps, and allows them to tolerate physical stress due to burial and abrasion, recovering and persisting despite disturbances.

Although there are no quantitative references in the literature on the amount of sediment that turfs accumulate at the edges of interaction with living coral tissue, this study showed that the turfs in reefs of the Tayrona NNP can accumulate up to $0.173 \mathrm{~g} \mathrm{~cm}^{-2}$ of total sediments, a figure that represents on average up to 21 and 14 times its biomass in Granate and Nenguange, respectively. Also, it is confirmed that there is a strong association between these two variables, that is, the higher the biomass, the greater the amount of retained sediments, particularly fine sediments. This great capacity that turfs have to retain sediments may be the main competitive advantage in interactions with living coral tissue, as stated by Zhiheng et al. (2019), given 
organismos que colonizan con esporas y plánulas, les permite capturar mayor cantidad de sedimento, el que a su vez les serviría de sustrato para anclarse y avanzar lateralmente llegando a cubrir los pólipos adyacentes, y les permite tolerar el estrés físico por enterramiento y abrasión, recuperándose y persistiendo a pesar de las perturbaciones.

Aunque en la literatura no existen referencias cuantitativas de la cantidad de sedimentos que acumulan los céspedes en bordes de interacción con tejido vivo coralino, este estudio demostró que los céspedes en arrecifes del PNN Tayrona pueden acumular hasta $0,173 \mathrm{~g} \cdot \mathrm{cm}^{-2}$ de sedimentos totales, cifra que representa en promedio hasta 21 y 14 veces su biomasa en Granate y Nenguange, respectivamente. Además, se confirma que existe una fuerte asociación entre estas dos variables, es decir que a mayor biomasa mayor es la cantidad de sedimentos retenidos, particularmente de sedimentos finos. Esta gran capacidad que tienen los céspedes de retener sedimentos, puede ser la principal ventaja competitiva en interacciones con tejido coralino vivo, como lo afirman Zhiheng et al. (2019), dado que las partículas de sedimentos que atrapan los filamentos algales al mezclarse con detritus y el moco que producen los corales forman masas que dificultan la actividad fotosintética de las zooxantelas de los pólipos del borde (Hauri et al., 2010), provocando así muerte progresiva del tejido coralino adyacente (Jompa y McCook, 2003b; Roy, 2004).

SegúnCaseyetal.(2014)yHarris(2015), loscéspedes compuestos por taxa morfológicamente más complejos y resistentes a la herbivoría y con abundantes sedimentos finos acumulados en sus frondas crean en la interface coral-césped ambientes hipóxicos que generan estrés en el tejido coralino y favorecen la colonización de microorganismos, algunos de ellos asociados con enfermedades coralinas. Por lo tanto, el seguimiento temporal de signos como la pérdida de la continuidad tegumentaria, decoloración y necrosis de los pólipos adyacentes facilita evaluar una condición de estrés en la interface coral-césped (Gómez-Cubillos, 2018), provocada probablemente por céspedes cargados con sedimentos. Finalmente, se aclara que según los resultados de este estudio y de otras investigaciones que adelantan los autores, se estima que la capacidad deletérea de los céspedes con sedimentos en bordes de interacción con corales depende no solo de la cantidad de sedimentos acumulados, sino también del tipo de sedimento, ya que las tasas anuales de pérdida lateral de tejido coralino se incrementan significativamente cuando la carga de sedimentos finos $(<63 \mu)$ con material orgánico aumenta. that the sediment particles that trap the algal filaments when mixing with detritus and the mucus produced by the corals, form masses that hinder the photosynthetic activity of the zooxanthellae of the border polyps (Hauri et al., 2010), thus causing progressive death of the adjacent coral tissue (Jompa and McCook, 2003b; Roy, 2004).

According to Casey et al. (2014) and Harris (2015), turfs composed of morphologically more complex taxa and resistant to herbivory, and with abundant fine sediments accumulated in their fronds, creating hypoxic environments in the coral-turf interface that generate stress in the coral tissue, and they favor the colonization of microorganisms, some of them associated with coral diseases. Therefore, the temporary monitoring of signs such as loss of integumentary continuity, discoloration, and necrosis of adjacent polyps, facilitates the evaluation of a stress condition in the coralturf interface (Gómez-Cubillos, 2018), probably caused by loaded turfs with sediment. Finally, it is clarified that according to the results of this study and other investigations carried out by the authors, it is estimated that the deleterious capacity of turfs with sediments at the edges of interaction with corals depends not only on the number of accumulated sediments but also on the sediment type since the annual rates of lateral loss of coral tissue increase significantly when a load of fine sediments $(<63 \mu)$ with organic material increases.

In sum, the structural description of the algal turfs that interact with massive corals on reefs of the Tayrona NNP provided valuable ecological information, because it allowed demonstrating that the structure of these assemblages is variable in space-time (seasonal replacement by macroalgal growth in Granate), facilitated making inferences about grazing pressure and allowed to quantify the capacity of turfs to accumulate sediments.

This information collectively highlights the competitive advantages of these assemblages in interactions with living coral tissue. Therefore, it is suggested to consider the abundance of algal turfs as an independent indicator in the methodology of the Indicator Protocol Condition Trend of Coral Areas in Colombia (Ramírez-Rincón et al., 2014), to provide useful information in understanding the current state of reef systems, make Spatio-temporal comparisons and show changes in reef communities, due to the dynamics of these assemblages. 
En suma, la descripción estructural de los céspedes algales que interactúan con corales masivos en arrecifes del PNN Tayrona suministró información ecológica valiosa, porque permitió demostrar que la estructura de estos ensamblajes es variable en el espacio-tiempo (reemplazo estacional por crecimiento macroalgal en Granate), facilitó realizar inferencias sobre la presión de pastoreo y permitió cuantificar la capacidad que tienen los céspedes para acumular sedimentos.

Esta información en conjunto relieva las ventajas competitivas de estos ensamblajes en interacciones con tejido vivo de coral. Por ello, se sugiere considerar la abundancia de céspedes algales como un indicador independiente en la metodología del Protocolo Indicador Condición Tendencia de Áreas Coralinas en Colombia (Ramírez-Rincón et al., 2014) para aportar información útil en la comprensión del estado actual de los sistemas arrecifales, realizar comparaciones espaciotemporales y evidenciar cambios en las comunidades de arrecife, en virtud a la dinámica de estos ensamblajes.

\section{AGRADECIMIENTOS}

Esta investigación se realizó con el apoyo y recursos financieros de la Universidad Nacional de Colombia, Sede Caribe y el Instituto de Estudios en Ciencias del Mar (Cecimar), a través de fondos obtenidos en la Convocatoria Nacional "Apoyo a proyectos de investigación y creación artística de la Universidad Nacional de Colombia 20172018" (código Hermes 39161). Igualmente se agradece a la UAESPNN - PNN Tayrona por incluir este proyecto dentro de su portafolio. Los resultados son parte de la tesis de MCGC con la que obtuvo su título de magíster en CienciasBiología, línea Biología Marina, de la UNAL, sede Caribe. Contribución 509 del Cecimar.

\section{ACKNOWLEDGEMENTS}

This research was carried out with the support and financial resources of the National University of Colombia, Caribbean Headquarters and the Institute of Studies in Marine Sciences (Cecimar), through funds obtained in the National Call "Support for Research Projects and Artistic Creation of the National University of Colombia 2017-2018" (Hermes code 39161). The UAESPNN - Tayrona NNP is also thanked for including this project in its portfolio. The results are part of the MCGC thesis with which he obtained his Master's degree in Sciences-Biology, Marine Biology Line from UNAL-Caribbean Headquarters. Contribution 509 of Cecimar.

\section{BIBLIOGRAFÍA/LITERATURE CITED}

Acosta, A., D, González, E. Navas y L. Sánchez. 2018. Estado de las formaciones coralinas del Parque Nacional Natural Tayrona años 2008-2018. Informe técnico de monitoreo ecosistémico ITF \# 1. Invemar. Santa Marta. 94 p.

Agresti, A. 2002. Categorical data analysis. Wiley-Interscience a John Wiley y Sons, inc., Publication (Eds.). 2 editions. Florida. 721 p.

Airoldi, L. 2003. The effects of sedimentation on rocky coast assemblages. Oceanogr. Mar. Biol. Annu. Rev., 41: 161-236.

Airoldi, L. and M. Virgilio. 1998. Responses of turf-forming algae to spatial variations in the deposition of sediments. Mar. Ecol. Prog. Ser., 165: 271-282.

Airoldi, L., F. Rindi, and F. Cinelli, F. 1995. Structure, seasonal dynamics and reproductive phenology of a filamentous turf assemblage on a sediment influenced, rocky subtidal shore. Bot. Mar., 38(3): 227-237.

Arthur, R., T.J., Done, and H. Marsh. 2005. Benthic recovery four years after an El Niño-induced coral mass mortality in the Lakshadweep atolls. Curr. Sci., 89(4): 694-699.

Barott, K.L., G.J. Williams, M.J.A. Vermeij, J. Harris, J.E. Smith, F.L. Rohwer, and S.A. Sandin. 2012. Natural history of coral-algae competition across a gradient of human activity in the Line Islands. Mar. Ecol. Prog. Ser., 460: 1-12. 
Bayraktarov, E. and C. Wild. 2014. Spatiotemporal variability of sedimentary organic matter supply and recycling processes in coral reefs of Tayrona National Natural Park, Colombian Caribbean. Biogeosciences, 11: 2977-2990.

Bellwood, D.R., T.P. Hughes, C. Folke, and M. Nystrom. 2004. Confronting the coral reef crisis. Nature, 429: 827-833.

Bender-Champ, D., G. Díaz-Pulido, and S. Dove. 2014. Warming and acidification promote cyanobacterial dominance in turf algal assemblages. Mar. Ecol. Prog. Ser., 517: 271-284.

Birrell, Ch.L., L.J. McCook and B.L. Willis. 2005. Effects of algal turfs and sediment on coral settlement. Mar. Pollut. Bull., 51: 408-414.

Birrell, Ch.L., L.J. McCook, B.L. Willis and G. Díaz-Pulido. 2008. Effects of benthic algae on the replenishment of corals and the implications for the resilience of coral reefs. Oceanogr. Mar. Biol. Annu. Rev., 46: 25-63.

Bonaldo, R.M. and D.R. Bellwood. 2011. Spatial variation in the effects of grazing on epilithic algal turfs on the Great Barrier Reef, Australia. Coral Reefs, 30: 381-390.

Bula-Meyer, G. 1990. Altas temperaturas estacionales del agua como condición disturbadora de las macroalgas del Parque Nacional Tairona, Caribe colombiano: una hipótesis. An. Inst. Invest. Mar. Punta Betín, 19-20: 9-21.

Burkepile, D.E. and M.E. Hay. 2010. Impact of herbivore identity on algal succession and coral growth on a Caribbean reef. PLoSOne, 5(1); 10.

Carpenter, R. and S. Williams. 2007. Mass transfer limitation of photosynthesis of coral reef algal turfs. Mar. Biol., 151, 435-450.

Casey, J. M., T.D. Ainsworth, J.H. Choat and S.R. Connolly. 2014. Farming behaviour of reef fishes increases the prevalence of coral disease associated microbes and black band disease. Proceedings of the Royal Society B: Biological Sciences, 281: 1-9.

Cetz-Navarro, N.P., L.I., Quan-Young, and J. Espinoza-Avalos. 2015. Morphological and community changes of turf algae in competition with corals. Sci. Rep., 5: 1-12.

Clarke, K. R. and R.M. Warwick. 2001. Change in marine communities: An approach to statistical analysis and interpretation. Primer-E, United Kindom. 174 p.

Connell, S. D., M.S. Foster, and L. Airoldi. 2014. What are algal turfs? Towards a better description of turfs. Mar. Ecol. Prog. Ser., 495: 299-307.

Copertino, M., S.D. Connell, and A., Cheshire. 2005. The prevalence and production of turf-forming algae on a temperate subtidal coast. Phycologia, 44: 241-248.

Díaz-Pulido, G. and J. Garzón-Ferreira. 2002. Seasonality in algal assemblages on up welling-influenced coral reefs in the Colombian Caribbean. Bot. Mar., 45: 284-292.

Díaz-Pulido, G. and L.J. McCook. 2002. The fate of bleached corals: patterns and dynamics of algal recruitment. Mar. Ecol. Prog. Ser., 232: 115-128.

Díaz-Pulido, G. and M. Díaz-Ruiz. 2003. Diversity of benthic marine algae of the Colombian Atlantic. Biota Colomb., 4(2): 203-246.

Díaz-Ruiz, M. 2010. El papel de la densidad de propágulos algales, la herbivoría y la sedimentación en la estructura de la comunidad de macroalgas en los arrecifes coralinos del Caribe colombiano. Tesis M.Sc., Ciencias-Biología, Línea Biología Marina, Universidad Nacional de Colombia, sede Caribe.

Fong, P. and V.J. Paul. 2011. Coral reef algae. 242-272. In: Dubinsky, Z. and N. Stambler (Eds). Coral Reefs: an ecosystem in transition. Springer Netherlands, Dordrecht.

Fricke, A., M. Teichberg, S. Beilfuss, and K. Bischof. 2011. Succession patterns in algal turf vegetation on a Caribbean coral reef. Bot. Mar., 54(2): 111-126.

Friedlander, A., R. Navas, M. Prada, A. Rodríguez-Ramírez, and S. Zea. 2014. Part II. Reports for individual countries and territories - Colombia. 196-201. In: Jackson J.B.C., M.K. Donovan, K.L. Kramer, and V.V. Lam (Eds.). 2014. Status and trends of Caribbean coral reefs: 1970-2012. Global Coral Reef Monitoring Network, IUCN, Gland, Switzerland. Washington. 306 p.

Garzón-Ferreira, J., M.C. Reyes-Nivia y A. Rodríguez-Ramírez. 2002. Manual de métodos del SIMAC (Sistema Nacional de Monitoreo de Arrecifes Coralinos) en Colombia. Informe final. Invemar, Santa Marta. $61 \mathrm{p}$.

Gómez-Cubillos, C. 2018. Interacciones coral-césped de algas y sus efectos en la comunidad coralina en el área de Santa Marta, Caribe colombiano. Tesis M.Sc., Ciencias-Biología, Línea Biología Marina, Universidad Nacional de Colombia, Sede Caribe.

Gómez-Cubillos, C., C.A. Daza-Guerra, B. Gavio y S. Zea. En prensa. Interacción coral-céspedes algales y su efecto sobre la comunidad arrecifal de isla Cayos de Alburquerque, Reserva de la Biosfera Seaflower. En: CCO (Eds). Resultados de la expedición científica Seaflower 2018, islas Cayo de Alburquerque.

Gómez-Cubillos, C., M.C. Gómez-Cubillos, A. Sanjuan-Muñoz y S. Zea. 2019. Interacciones de corales masivos con céspedes algales y otros organismos en arrecifes del Parque Nacional Natural Tayrona. Bol. Invest. Mar. Cost., 48(2): 143-171.

González, M.T. y A. Pérez. 2009. Estadística aplicada. Una visión experimental. Díaz de Santos, Bogotá. 786 p.

Gorgula, S.K. and S.D. Connell. 2004. Expansive covers of turf-forming algae on human-dominated coast: The relative effects of increasing nutrient and sediment loads. Mar. Biol., 145(3): 613-619.

Gowan, J.C., J.S. Tootell, and R.C. Carpenter. 2014. The effects of water flow and sedimentation on interactions between massive Porites and algal turf. Coral Reefs, 33(3): 651-663.

Harris, J.L. 2015. The ecology of turf algae on coral reefs. PhD Thesis, University of California. $201 \mathrm{p}$.

Harris, J.L., L.S. Lewis, and J.E. Smith. 2015. Quantifying scales of spatial variability in algal turf assemblages on coral reefs. Mar. Ecol. Prog. Ser., 532, $41-57$. 
Hauri, C., K.E. Fabricius, B. Schaffelke, and C. Humphrey. 2010. Chemical and physical environmental conditions underneath mat- and canopy-forming macroalgae, and their effects on understorey corals. PLoS ONE, 5: 10.

Hay, M. 1981. The functional morphology of turf-forming seaweeds: persistence in stressful marine hábitats. Ecology, 62(3): 739-750.

Hughes, T.P. 1996. Demographic approaches to community dynamics: a coral reef example. Ecology, 77: 2256-2260.

Hughes, T.P., M.J. Rodríguez, D.R. Bellwood, D. Ceccarelli, O. Hoegh-Guldberg, L. McCook, N. Moltschaniwskyj, M.S. Pratchett, R.S. Steneck, and B. Willis. 2007. Phase shifts, herbivory and the resilence of coral reefs to climate change. Curr. Biol., 17: 360-365.

Jackson J.B.C., M.K. Donovan, K.L. Kramer, and V.V. Lam (Eds). 2014. Status and trends of Caribbean coral reefs: 1970-2012. Global Coral Reef Monitoring Network, IUCN, Gland, Switzerland. 306 p.

Johnson, M.D., S. Comeau, C.A. Lantz, and J.E. Smith. 2017. Complex and interactive effects of ocean acidification and temperature on epilithic and endolithic coral-reef turf algal assemblages. Coral reefs, 36(4): 1-12.

Jompa, J. and L.J. McCook. 2003a Coral-algal competition: macroalgae with different properties have different effects on corals. Mar. Ecol. Prog. Ser., 258: 87-95.

Jompa, J. and L.J. McCook. 2003b. Contrasting effects of turf algae on corals: masive Porites spp. are unaffected by mixed-species turfs, but killed by the red alga Anotrichium tenue. Mar. Ecol. Prog. Ser., 258: 79-86.

Jones, G., L. Santana, L. McCook, and M. McCormick. 2006. Resource use and impact of three herbivorous damselfishes on coral reef communities. Mar. Ecol. Prog. Ser., 328: 215-224.

Kennelly, S. J. 1987. Inhibition of kelp recruitment by turfing algae and consequences for an Australian kelp community. J. Exp. Mar. Biol. Ecol., 112: 49-60.

Kroeker, K., F. Micheli, and C. Gambi. 2013. Ocean acidification causes ecosystem shifts via altered competitive interactions. Nat. Clim. Change, 3: 156-159.

Littler, D.S. and Littler, M.M. 2000. Caribbean reef plants. Offshore Graphics, Washington. 247 p.

Littler, M.M., D.S. Littler and B.L. Brooks. 2006. Harmful algae on tropical coral reefs: bottom-up eutrophication and top-down herbivory. Harmful Algae, 5: 565585.

Márquez, J.C. and S. Zea. 2012. Parrotfish mediation in coral mortality and bioerosion by the encrusting, excavating sponge Cliona tenuis. Mar. Ecol., $33: 417-426$.

McManus, J.W. and J.F. Polsenberg. 2004. Coral-algal phase shifts on coral reefs: ecological and environmental aspects. Prog. Oceanogr., 60: $263-279$.

Morrison, D. 1988. Comparing fish and urchin grazing in shallow and deeper coral reef algal communities. Ecology, 69: 1367-1382.

Nugues, M.M. and C.M. Roberts. 2003. Coral mortality and interaction with algae in relation to sedimentation. Coral Reefs, 22: 507-516.

Ober, G.T., G. Díaz-Pulido, and C. Thornber. 2016. Ocean acidification influences the biomass and diversity of reef-associated turf algal communities. Mar. Biol.: 163-204.

Purcell, S.W. and D.R. Bellwood. 2001. Spatial patterns of epilithic algal and detrital resources on a windward coral reef. Coral Reefs, 20: 117-125.

Roy, R.E. 2004. Turf algal/sediment (TAS) Mats: a chronic stressor on scleraactinian corals. PhD Thesis, University of Texas at Austin. 191 p.

Sokal, R.R. and F.J. Rohlf. 1981. Biometry. The principles and practice of statistics in biological research. 2nd Ed. W.H. Freemen and Co., San Francisco, 867 p.

Sousa, W.P. 1979. Experimental investigations of disturbance and ecological succession in a rocky intertidal algal community. Ecol. Monogr., 49(3): 227-254.

Swierts, T. and M.J.A. Vermeij. 2016. Competitive interactions between corals and turf algae depend on coral colony form. PeerJ., 4: e1984. https://doi.org/10.7717/ peerj. 1984

Taylor, W. 1960. Marine algae of the eastern tropical and subtropical coast of the Americas. Lord Baltimore Press/Universidad de Michigan, Michigan. 870 p.

Underwood, A. 1997. Experiments in ecology: their logical design and interpretation using analysis of variance. Cambridge University Press, New York. 504 p.

Vega-Sequeda, J., A. Rodríguez-Ramírez y M.C. Reyes-Nivia. 2008. Formaciones coralinas del área de Santa Marta: Estado y patrones de distribución espacial de la comunidad bentónica. Bol. Invest. Mar. Cost., 37(2): 87-105.

Wanders, J.B.W. 1976. The role of benthic algae in the shallow reef of Curaçao (Netherlands Antilles). I: primary productivity in the coral reef. Aquat. Bot., 2: 235270.

Wynne, M. 2011. A check-list of benthic marine algae of the tropical and subtropical western Atlantic: third revision. Nova Hedwigia, 140: 1-166.

Wynne, M. 2017. A checklist of benthic marine algae of the tropical and subtropical western Atlantic: fourth revision. Nova Hedwig. Beih., 145: 1-202.

Zea, S. 1994. Patterns of coral and sponge abundance in stressed coral reefs at Santa Marta, Colombian Caribbean. 257-264. In: Van Soest, R., Van Kempen, T., and J. C. Bracekman (Eds.), Proceedings of the $4^{\text {th }}$ international Porifera Congress. Amsterdam, Netherlands. 544 p.

Zhiheng. L., Y. Kefu, Y. Wang, X. Huang, and L. X. 2019. Coral-algal interactions at Weizhou Island in the northern South China sea: variations by taxa and the exacerbating impact of sediments trapped in turf algae. PeerJ, 7: e6590. https://doi.org/10.7717/peerj.6590 